\title{
Article
}

\section{Agile capabilities as necessary conditions for maximising sustainable supply chain performance: An empirical investigation}

Geyi, Danasabe Godwin, Yusuf, Yahaya, Menhat, Masha S., Abubakar, Tijjani and Ogbuke, Nnamdi Johnson

Available at http://clok.uclan.ac.uk/30596/

Geyi, Danasabe Godwin, Yusuf, Yahaya ORCID: 0000-0001-6045-3245, Menhat, Masha S., Abubakar, Tijjani and Ogbuke, Nnamdi Johnson (2019) Agile capabilities as necessary conditions for maximising sustainable supply chain performance: An empirical investigation. International Journal of Production Economics, 222 . p. 107501. ISSN 0925-5273

It is advisable to refer to the publisher's version if you intend to cite from the work. http://dx.doi.org/10.1016/j.ijpe.2019.09.022

For more information about UCLan's research in this area go to http://www.uclan.ac.uk/researchgroups/ and search for <name of research Group>.

For information about Research generally at UCLan please go to http://www.uclan.ac.uk/research/

All outputs in CLoK are protected by Intellectual Property Rights law, including Copyright law. Copyright, IPR and Moral Rights for the works on this site are retained by the individual authors and/or other copyright owners. Terms and conditions for use of this material are defined in the policies page. 


\title{
Agile capabilities as necessary conditions for maximising sustainable supply chain performance: an empirical investigation
}

\author{
Dan'Asabe Godwin Geyi ${ }^{1}$, Yahaya Yusuf ${ }^{1}$, Masha S. Menhat ${ }^{2}$, Tijjani Abubakar ${ }^{3}$, Nnamdi J. Ogbuke ${ }^{1}$ \\ ${ }^{1}$ Lancashire School of Business and Enterprise, University of Central Lancashire, Preston PR1 2HE \\ ${ }^{2}$ Faculty of Maritime Studies, University of Malaysia Terengganu, 21030 Kuala Terengganu, \\ Terengganu, Malaysia \\ ${ }^{3}$ Department of Management and Information Technology, Faculty of Management Science, \\ Abubakar Tafawa Balewa University, Bauchi, Nigeria
}

\begin{abstract}
The effects of agile practices on sustainability performance measures require examination and clarification especially given the wider diffusion of agility and the increasing embrace of sustainability. More importantly, the role agility plays in enhancing or not enhancing sustainability performance is not fully understood. Therefore, we explored the interaction effects between agile practices, sustainable practices, operational performance objectives and sustainable performance of organisations. A survey of higher carbon and energy intensive supply chains in the UK was carried out with a net 311 respondent organisations. The results show that there is a significant correlation between sustainable supply chain practices and agile practices. Also, the results indicate that agile practices do have a positive influence on both sustainability performance and operational performance objectives. Whilst the link between agility and operational performance is not new, what is new here is the connection between agile practices and sustainability performance. In addition, the findings show that sustainable supply chain practices predict both sustainability performance and operational performance. But more importantly, when these relationships are mediated by agile practices, the performance impacts of sustainability practices are enhanced. These findings question the usefulness of implementing sustainability practices within the supply chains when there is a lack of agile capabilities. In other words, the results suggest that agile capabilities are necessary conditions for maximising the outcomes of implementation of sustainability practices. As such, managers who want to maximise the outcomes of their sustainability campaigns should consider concurrent implementation of sustainability practices and agile practices.
\end{abstract}

Keywords: Supply chain agility; Sustainable supply chain; Competitive performance objectives; Sustainability performance measures and Organisational performance criteria. 


\section{Introduction}

The growing concerns about the environment, in particular the impact of climate change, has led to a focus on unsustainable patterns of behaviours in manufacturing supply chains. There is a recognition that the climate is changing, and further change is inevitable without reducing greenhouse gas emissions such as carbon dioxide, methane and nitrous oxide and various fluorocarbons (Pierre et al., 2019). Broadly speaking, these emissions as they relate to supply chains' activities are often referred to as their 'carbon footprint' (Yusuf et al., 2013; Hannibal and Kauppi, 2018)

There is a clear consensus that supply chains' carbon footprint should be reduced (Jabbour et al., 2018) and that enterprises' operations decisions have extensive impacts on the natural environment and resources. It is essential therefore to consider the impacts of industrial operations on the use of scarce resources and the level of waste generation across the supply network (Adham et al., 2015). Other factors such as the growing global population cause increase in demand for scarce resources like energy, water, raw materials and land. As a result, these resources are subject to greater competition, thereby leading to resource conflict (Hofmann et al., 2018). Manufacturers will, therefore, be pushing to use less materials, energy and other inputs; make better use of alternative materials; and embrace reuse, recycling, recovery, remanufacturing of end of life products and producing robust products for sustainable consumption (Geissdoerfer et al., 2018; Tonelli et al., 2013). A major current challenge, thus, is about increasing the sustainability of industrial production.

Several studies have explored agility and sustainability practices (Blome et al., 2013; Marshall et al., 2015; Dubey et al., 2018). But these practices have rarely been looked at together. Therefore, this study aims to investigate the relationships between agility and sustainability and their impacts on sustainability performance of industries. This is predicated upon the fact that whilst agility or sustainability has been correlated with financial measures and operational performance objectives, there is no empirical study currently that examines the influence of agile practices on the extent to which organisations could translate sustainability practices into sustainability performance (Ciccullo et al., 
2018; Chen et al., 2017). In particular, it is not clear if agility serves as an effective mediator of sustainability.

Sustainable supply chain, according to Roy et al (2018), involves 'the management of financial and non- financial measures as well as the encouragement of good leadership practices within the supply chains'. Similarly, Marshall et al (2015) contend, it is a set of practices aimed at minimising the environmental impacts and enhancing the social welfare of different stakeholders while contributing to the long-term financial growth of the entities within the supply chain. Azevedo et al. (2012) and Dües et al. (2013) distinguish between green and sustainable supply chain paradigms and contend that green supply chain paradigm involves practices aimed at minimising the environmental impacts of the supply chain whilst sustainable supply chain encompasses the triple-bottom line of environmental, social and economic objectives. In furtherance of this, a number of work have examined the relationship between adoption of sustainable supply chain practices and organisational performance. Such work includes Golicic and Smith (2013), Rao and Holt (2005) and Paulraj et al. (2017) who have demonstrated a positive correlation between sustainability and organisational performance. However, there are contrasting reports (Esfahbodi et al., 2017; Winn et al., 2012; Green et al., 2012; Hahn et al., 2010) of sustainability having a negative impact on firms' profitability indicating a need to find ways to maximise the performance advantage of implementation of sustainability practices. The challenge for organisations, thus, is how to integrate social and environmental sustainability practices with agile supply chain capabilities to develop unique capabilities to improve their sustainability competitiveness (Ciccullo et al., 2018; Chen et al., 2017), which is the subject of investigation of work reported here.

Agile methods focus on people, technology and processes while collaborating with customers and adapting to change (Serrador and Pinto, 2015) to take advantage of windows of opportunities. It is a business model that allows companies to use market knowledge and partnerships to exploit profitable opportunities in a volatile marketplace (Naylor et al., 1999, p.108). This idea has been extended beyond organisation's boundaries to include the activities of the supply chain, emphasising the need for strategic alliances, knowledge transfer, information sharing, aligning resource capabilities and effective leadership practices across supply chain (Dyer et al., 2018; Dubey et al., 2018). According to Lee 
(2004), agile supply chains is about being responsible and adaptable to the customer requirements while the risk of supply chain disruptions is avoided. Supply chain agility is the ability of firm to sense shortterm, temporary changes in supply chain and market environment as well as to quickly adjust to those changes (Aslam et al., 2018; Eckstein et al., 2015). Agile supply chain capabilities have been extensively researched and linked to superior organisational performance. However, whilst it has been established that agility on the one hand induce better operational performance and sustainability on the hand could potentially enhance indicators of environmental and social sustainability, the interactive effects of both have not been examined. In fact, Ciccullo et al. (2018) called for the development of a model that integrates agility practices with sustainability practices and advocated for empirical studies of the relationships between the two set of practices. Therefore, in this study, we explored agility as mediator of sustainability and examined the roles of agile capabilities in maximising the transformation of sustainability practices into environmental and social sustainability performance. Prior to that, we developed a single integrated conceptual model linking agile practices, sustainable supply chain practices with organisational performance criteria (operational performance objectives and sustainability performance) and proposed the following hypotheses:

H1: Agile practices have a positive effect on sustainability performance.

H2: Agile practices have a positive effect on operational performance objectives.

H3: Sustainable supply chain practices have positive effects on operational performance objectives.

H4: Sustainable supply chain practices have positive effects on sustainability performance objectives.

H5: Agile practices mediate the relationships between sustainable supply chain practices and sustainability performance.

H6: Agile practices mediate the relationships between sustainable supply chain practices and operational performance objectives.

H7: Sustainable supply chain practices have positive effects on agile practices. 
The subsequent section 2 reviews the extant literature on sustainable supply chain and supply chain agility. Section 3 presents the conceptual model and hypotheses, whilst section 4 discusses the methodology. The data examination, results and testing of hypotheses with data drawn from $311 \mathrm{UK}$ organisations followed by discussions are in section 5 and finally, section 6 states the conclusion and future research directions.

\subsection{Literature review}

\subsection{Sustainable supply chain practices}

The supply chain is "a network of connected and interdependent organisations mutually and cooperatively working together to control, manage and improve the flow of materials and information from suppliers to end users" (Christopher, 2016, p. 3). It is a strategic management tool used to enhance overall customer satisfaction, which is intended to improve the profitability and competitiveness of organisations. In short, Supply chain management embraces the integration of all key business processes across the supply chain (Lambert and Enz, 2017). Given the growing magnitude of environmental and social problems, however, the traditional supply chain models have become inadequate, as a basis for identifying important emerging sources of sustainable competitive objectives. (Ageron et al., 2012; Grimm et al., 2014; Hofmann et al., 2018; Wong et al., 2018). Unlike the traditional supply chain model, sustainable supply chain considers the social and environmental impacts of the production processes as goods flow through the supply chain (Marshall et al., 2015). In other words, sustainable supply chain paradigm is a set of supply chain initiatives aiming at reducing the environmental impact and improving the social condition of different members of the chain, while boosting innovation, resource-efficiency, reputation and market share (Sancha et al., 2016; Stindt et al., 2016).

Over the years, the concept of sustainable supply chain management has evolved to include activities such as ISO 14001, SA 8000 and codes of conducts (Darnall and Edwards, 2006; Orzes et al., 2017; 
Treacy et al., 2019) in addition to due diligence in supply of conflict minerals (Hofmann et al., 2018) and restriction of the use of hazardous materials (Blome et al., 2014). Some studies also have looked at the implementation of proactive sustainable product design within multi-tier supply chains (Morais and Silvestre, 2018; Grimm et al, 2014; Wilhelm et al., 2016). While others consider sustainable procurement (Vachon and Klassen, 2006; Paulraj et al., 2017; Zhu et al., 2013; Morali and Searcy 2013) and investment recovery (Zhu et al., 2013, Zhu and Sarkis, 2007; Nasir et al., 2017) as sustainable practices. Recently, Marshall et al. (2015), Mani et al. (2018); and Zhu and Lai (2019) maintained that it is important also to understand the social issues that influence each level of supply chain and their stakeholders. These include health and safety management procedures, workers' welfare, human rights violations, product and process safety amongst others (Marshall et al., 2015; Chin et al., 2015). Given the multi-characteristics of sustainable supply chain practices, as summarised in table 1a, this research focuses on five major sub-constructs of sustainable practices. These are sustainable products design, sustainable procurement, environmental management system, investment recovery and social sustainability practices. These practices relate to the main internal and external activities and operations in sustainable supply chain management, as suggested by Zhu et al., 2008 and others (Paulraj et al., 2017; Su et al., 2015).

Social sustainability practices are about the management of social issues in the entire supply chain (Mani et al., 2018). Marshall et al. (2015) grouped social practices into two categories. These are basic category, which includes safety, welfare, and health, whilst advanced category involves product and process related issues. Environmental sustainability can be facilitated, amongst other approaches, via closed-loop supply chain - a circular way of doing business where wastes are recycled as raw materials and/or with the end of life products reused as input (Zhu et al., 2013; Kleindorfer et al., 2005). This practice concerned with reducing negative environmental impacts by attempting to integrate obsolete, and excess capital assets back in to reverse logistics processes so that assets may be recovered or disposed of (Zhu et al., 2008). This shift in thinking is likely to generate real competitive benefits and differentiation. It can also help organisations to maximise cost savings. A circular approach provides companies with an alternative pattern of resource use and creating more value from each unit of the 
resource through recovery and regenerating products at the end of their service lives (Choi and Hwang, 2015).

\subsection{Agile approaches}

The term 'agile manufacturing' was first used by a group of researchers at Iacocca Institute, Lehigh University, in 1991 to describe the practices observed as important aspects of manufacturing system (Ren et al., 2003). Goldman et al. (1995) defined agility and developed four dimensions of agility including delivering value to the customers, being ready for change, valuing human knowledge and skills, and forming virtual partnerships. Mathiyakalan et al. (2005) argued that agility is a capability of firms to detect changes in its business environment and reconfigure its resources, processes and strategies to rapid responses to a changing environment. In line with Naylor (1999), agility involves using market knowledge and collaboration to exploit profitable opportunities in a volatile market place. In short, Agile approaches focus on people, technology that works well, working with customers and adapting to change.

In order to agile, organisations require a set of enablers. Bottani (2010) argued that agile enablers are capabilities, which allow to promptly respond to changing business environment. Other literature, such as Aslam et al. (2018); Dubey et al. (2018); Eckstein et al. (2015); Ketchen and Hult (2007) and Lee (2004) identified market sensing capability, supply chain alignment and adaptability as some of the key precursors of supply chain agility. In consonance with these drivers, Conforto et al. (2014) itemised a set of agility enablers including knowledge management, strong leadership commitment, organisation learning, organisational culture, multidisciplinary teams, decentralised decision-making, customer and stakeholder involvement.

Besides, Yusuf et al. (2004) classified agile supply chain capabilities into reach and range of upstream and downstream activities supported by trust-based collaboration. The greater the degree of reach and range practices the better the visibility of supply chain operations (Yusuf et al. 2004). Similarly, the reach and range dimensions, according to Dyer and Singh (1998), are measured using related 
capabilities of supply chain maturity such as inter-firm collaboration, joint resource capabilities, knowledge-sharing, and effective leadership practices.

In addition to the stated enablers, Vinodh et al. (2010) group agility enablers into technology and management categories. The former includes the integration of information, computer-aided design and production, virtual enterprise, reverse engineering, rapid prototyping. The management enablers include lean approach, total product management, supply network management. Recently, Gunasekaran et al. (2018) defined agile supply chain practices in term of five enabling competencies of transparent customisation, supply network, intelligent automation, total employee empowerment and technology integration. In order to operationalise the concept of agility in the supply chain, this study used five important capabilities including market sensitivity, network collaboration, process alignment, technology integration, and employee empowerment (Gunasekaran et al., 2018; Lin et al., 2006; Martinez-Sanchez and Lahoz-Leo, 2018). The Table 1a below displays the key enabling attributes of agile supply chain mentioned and their sources.

Table 1a: The summary of key attributes of sustainable supply chain practices and agile practices

\begin{tabular}{|c|c|c|}
\hline Constructs & Attributes & Sources \\
\hline $\begin{array}{l}\text { Sustainable supply chain } \\
\text { practices }\end{array}$ & $\begin{array}{ll}\text { - } & \text { Environmental management systems } \\
\text { - } & \text { Sustainable design } \\
\text { - } & \text { Investment recovery } \\
\text { - } & \text { Sustainable procurement } \\
\text { Social sustainability practices }\end{array}$ & $\begin{array}{l}\text { Zhu et al., 2013; Wu et al., 2012; } \\
\text { Esfahbodi et al., 2017; Blome et al., } \\
\text { 2014; Paulraj et al. 2017; Wong et al. } \\
\text { 2012; Huq et al., 2016; Mani et al., } \\
\text { 2018; Zhu and Lai, 2019; Marshall et } \\
\text { al., 2015. }\end{array}$ \\
\hline Agile practices & $\begin{array}{ll}\text { - } & \text { Market sensitivity } \\
\text { - } & \text { Employee empowerment } \\
\text { - } & \text { Process alignment } \\
\text { - } & \text { Technology integration } \\
\text { - } & \text { Network collaboration }\end{array}$ & $\begin{array}{l}\text { Gunasekaran et al. 2018; Aslam et al. } \\
\text { 2018; Dubey et al. 2018 Carvalho et } \\
\text { al. 2017; Martinez-Sanchez and } \\
\text { Lahoz-Leo 2018; Lin et al., 2006; } \\
\text { Eckstein et al. 2015; Conforto et al. } \\
\text { 2014; Bottani 2010; Ketchen and } \\
\text { Hult } 2007 \text { and Lee 2004. }\end{array}$ \\
\hline
\end{tabular}

\subsection{Sustainability performance criteria}

Performance measures are important to companies in the supply chain in order to assess performance against set objectives and identify loopholes in performance (Yusuf et al., 2018). The ability to create 
a baseline is a necessity for any performance measurement system (Beske-Janssen et al., 2015). A performance measurement system can be defined as the set of metrics used to quantify both the efficiency and effectiveness of actions (Neely et al., 2005). There appears to be a growing recognition that the measures of performance that companies have traditionally used are inappropriate for manufacturing supply chains (Yusuf et al., 2018; Neely et al., 2005). This may have been because they: encourage short-termism; lack strategic focus, and do not provide data of social and environmental issues; and it fails to provide information on what their customers want and what their competitors are doing (Kaplan and Norton, 1992). Therefore, it is important that today's performance measurement system must address the three sustainability dimensions without giving primacy to the economic outcomes over social and environmental effects (Pagell and Shevchenko, 2014).

Environmental sustainability performance pertains to reducing the natural resources consumption such as materials, water, energy and the atmosphere, amongst others. Whilst there is an understandable concern that the supply chain's carbon footprint should be minimised, it must be recognised that suppliers' decisions have a wider impact on resources generally. Besides, it is important to consider the effect of human and economic activities on the source of raw materials across the entire supply chain. Yusuf et al. (2013) termed this as the protection of scarce resources required to satisfy people requirements. Waste, including external waste, inflicts internal cost (Sarkis et al., 2011). Even in the absence of laws, wasteful use of materials, water, energy and neglect of greenhouse gases are not only harmful to the environment but changing climate is likely to increase the vulnerability of global supply chains and thus exerting pressures on manufacturers to reduce their greenhouse gas emissions. There is an overwhelming agreement that the climate is changing, and further change is inevitable without reductions of greenhouse gas emissions such as Hydrofluorocarbons, perfluorocarbons, sulphur hexafluoride, carbon dioxide, methane and nitrous oxide. The multiple consequences that come with a warmer climate have escalated the kind of attention given to environmental performance. Environmental performance may also comprise of minimised air emissions, reduced material input, increased energy efficiency, reduced discharge of solid and toxic waste, and decreased use of natural resources, amongst others (Paulraj et al., 2017; Zhu et al., 2008; 2013; Zhu and Sarkis 2004). 
The importance of social sustainability performance has been emphasised in the literature (BeskeJanssen et al., 2015; Walker et al., 2014). Social performance is the means to the twin objectives of achieving environmental and economic sustainability (Yusuf et al., 2013). Chen et al. (2017) grouped social performance into two basic categories: social capital and human capital. Social capital, on one hand, concerns respecting the rights of the communities in which the resources are located, improving better quality of lives of people without damaging the environment and not overexploiting the resources contained in it (Chin et al., 2015; Yusuf et al., 2013). This also involves humane working conditions at suppliers' plants, fair treatment of customers (product and process safety), and social investment at communities where suppliers operate (Krause et al., 2009; Sarkis et al., 2010). The human capital, on the other hand, concerns improved health and safety of workers, fairness in the working environment, workers diversity and inclusions, sustainable skills development of workers, welfare of workers and the level of employee commitment, amongst others (Jennings, 2013; Carter and Rogers, 2008; Porter and Kramer, 2006; Krause et al., 2009).

The economic performance focuses on achieving sales growth and increasing profitability. Here, the critical linkage is the impact that social and environmental action can have on sales volume and customer satisfaction. There are studies that indicate a positive connectedness between sustainability factors and sales growth (Sarkis et al., 2011). For example, Paulraj et al. (2017) show that sustainable supply chain practices improve economic performance such as profit as a percentage of sales, return on assets and increase in market share. This can be through the efficient use of resources, where products use a smaller amount of materials and energy.

It can also be argued that good social and environmental activities may strengthen the likelihood that customers will remain loyal to the supplier. The higher levels of customer retention lead to greater sales and profit. Naturally, this occurs because satisfied customers are more likely to place a greater proportion of their purchases with the supply chains. Nonetheless, to sustain the supply chain, productivity improvement is important in order to boost market share. Market share is an indicator of financial performance (Yusuf et al., 2013; 2014). Just as powerful and important is cash flow. Strong 
positive cash flow has become as much a desired objective of management as profit. The pressure on most organisations is to improve the productivity of capital to make the resources liquid. In this regard, it is usual to use the concept of return on investment where it is defined as the ratio between the net profit and the capital that was employed to produce that profit.

\subsubsection{Operational performance objectives}

Operational performance objectives arise from the ways in which a firm chooses to compete in the marketplace and the types of markets it pursues (Porter, 2004). In competitive markets, customers drive markets and markets drive organisational behaviours. Customers make purchasing decisions for a variety of reasons such as cost or service attributes relating to a purchase. Organisations must position themselves to meet the buyer's requirements. There are numerous important operational competitive attributes that determine the competitive position of an organisation in the marketplace. These may include cost, quality, delivery reliability, speed of delivery, flexibility and innovation (Yusuf et al., 2014).

A low-cost position allows the company to use aggressive pricing and high sales volume (Hart, 1995). The organisation keeps the cost of products and services low to provide its customers with better value for money. Focus on this attribute will be important when an organisation is in competition with lowprice competitors. Low cost alone may not be enough to attract and keep customers and the company may need to compete on other dimensions too. The quality objective is the ability to deliver on quality conformance. There are two aspects of quality, these include product/service quality and process quality. Process quality is important for all organisations competing in the market because no customer wants products with defects. It determines the reliability of the product/service. Continuous improvement of quality and reliability of products and services offered will be essential in the market being served. The operational objectives must be to specify product/services quality at the level acceptable to the market and consistently conform to specifications.

Reliability performance objective means adherence to the terms and conditions earlier agreed with the customer. Delivery on time or ahead of time may help the organisation to establish a competitive 
advantage, which may be critical to securing a competitive position in the market (Yusuf et al., 2014). Failure to deliver on time may lead to a loss of trust. The emphasis on reliability has increased because of instability in the market environment (Gordon and Sohal, 2001).

It is important for manufacturers to deliver on cost, quality and reliability objectives. The increase in competition and rapid technological change have shifted attention to speed. The speed at which a product or service can be delivered may determine the competitive advantage in some market. Speed means timely fulfilment of scheduled orders and developing new solutions ahead of competitors. Enhanced operations speed requires the elimination of non-value-added activities in supply chain business processes (Gordon and Sohal, 2001). Increasing speed encourages waste reduction, while materials spend less time in inventory, thereby minimising operational costs.

There is emphasis on operational flexibility and for companies to accept the challenge of delivering an expected product/service, despite a sudden change in customer demand. In the present social and environmental changes, flexibility entails being able to change products or production processes quickly. Manufacturers may need to develop and introduce new products swiftly for its customers. Innovation, new design, access to capabilities in managing new technologies and process reconfiguration may all be part of being flexible. Another measure of organisational performance is innovation. Innovation involves the thoughtful application of information, imagination and initiative to deliver values from resources. In the context of business, innovation is achieved when an idea is applied to further satisfy the needs and expectations of customers (Guisado-González et al., 2016). The financial, operational, environmental and social performance measures discussed above are summarised in Table $1 b$.

Table 1b: Summary of the dimensions of sustainability and operational performance measures

\begin{tabular}{|c|c|c|}
\hline Dimensions & Indicators & Sources \\
\hline Financial performance & $\begin{array}{ll}\text { - } & \text { Increase in Sales } \\
\text { - } & \text { Increase in Profit } \\
\text { - } & \text { Increase in overall market share } \\
\text { - } & \text { Increase in customers' satisfaction } \\
\text { - } & \text { Improvement in firm's } \\
& \text { reputation }\end{array}$ & $\begin{array}{l}\text { Yusuf et al., 2013; } 2014 \text {; Golicic } \\
\text { and Smith, 2013; Paulraj et al., } 2017\end{array}$ \\
\hline
\end{tabular}




\begin{tabular}{|c|c|c|}
\hline Operational Performance & $\begin{array}{ll}\text { - } & \text { Costs } \\
\text { - } & \text { Quality } \\
\text { - } & \text { Speed } \\
\text { - } & \text { Reliability } \\
\text { - } & \text { Flexibility } \\
\text { - } & \text { Innovation } \\
\end{array}$ & $\begin{array}{l}\text { Yusuf et al., } 2014 \text {; Zhu et al., } 2013 \text {; } \\
\text { Ren et al., } 2003 \text {; Blome et al., } 2013 \text {; } \\
\text { Eckstein et al., } 2015\end{array}$ \\
\hline Environmental performance & $\begin{array}{ll}\text { - } & \text { Reduction in solid wastes } \\
\text { - } & \text { Decrease in use of natural resources } \\
\text { - } & \text { Increased energy efficiency } \\
\text { - } & \text { Reduction in water usage } \\
\text { - } & \text { Reduced air pollution } \\
\text { - } & \text { Decrease in consumption toxic chemicals } \\
\text { - } & \text { Decrease in frequency for environmental } \\
\text { - } & \text { Impridents avement in an enterprise } \\
\text { environmental situation }\end{array}$ & $\begin{array}{l}\text { Paulraj et al., 2017; Zhu et al., } \\
2013 \text {; Wong et al., } 2012 \text {; Esfahbodi } \\
\text { et al., } 2017 \text {; Blome et al., } 2014\end{array}$ \\
\hline Social Performance & $\begin{array}{l}\text { - Increase in community involvement } \\
\text { - Improvement in employee welfare } \\
\text { - Improvement in health and safety of } \\
\text { - } \text { Imprkers } \\
\text { - } \text { Respect human rights } \\
\text { - Improved product safety } \\
\text { - Improved process safety } \\
\text { - Improvement in social investment } \\
\end{array}$ & $\begin{array}{l}\text { Paulraj et al., 2017; Jennings, 2013; } \\
\text { Krause et al., 2009; Chin et al., 2015; } \\
\text { Sarkis et al., 2010; Klassen and } \\
\text { Vereecke, } 2012\end{array}$ \\
\hline
\end{tabular}

\section{Conceptual model and hypothesis development}

\subsection{Conceptual model}

This study is grounded in the dynamic capabilities view. This theory is the extension of the relational theory (Dyer et al., 2018). Generally speaking, the resource-based view explores how certain assets and capabilities serve as a base for competitive advantage and superior performance (Barney, 1991). This approach views the company as a bundle of resources and emphasises that resource heterogeneity exists inside the firm. But there have been a lot of criticisms of the relevance of resource-based view theory to current sustainable supply chain design. Hart (1995), in propounding a natural resource-based view, argued that models of sustainable competitive advantage need to be expanded to include the constraints and challenges that the natural environment places on firms, and how resources and capabilities rooted in the firm's interaction with its natural environment can lead to competitive advantage. The Natural Resource-Based View of the firm was further explored by Hart and Dowell (2011) in the light of dynamic capabilities. The natural resource-based view (NRBV) role was examined to understand how firms account for environmental sustainability in their quest for competitive advantage. Lavie (2006) mentioned that unique resources exist at the supply network resources of interconnected firms whilst 
Ketchen and Hult (2007) maintained that companies should rather invest in cooperation that allows them to create relation-specific instead of firm-specific rent. In light of this, Dyer et al. (2018) argued that the NRBV fails to consider how cooperation, value creation, and value capture unfold over time. They suggest that the dynamic capabilities view is critical because it provides greater insight into understanding both what drives cooperation for value creation and what leads to competition for value capture.

Accordingly, dynamic capability depicts the organisation's ability to integrate, build and modify internal and external capabilities to address quickly shift in the people expectations (Teece et al., 1997' p. 516). As Aslam et al. (2018), Blome et al. (2014), Eckstein et al. (2015) and Augier and Teece (2009) pointed out, dynamic capabilities allow organisations to sense and seize opportunities, and to sustain competitive advantage through aligning and adapting resource capabilities. In the context of the supply chain, dynamic capability emerges when companies engage their employees in understanding customer requirements and interpret such needs to permit fast communication in the entire supply chains.

Following Dubey et al. (2018), Beske et al., (2014), Aslam et al. (2018), Ketchen and Hult (2007), Blome et al. (2014) and Eckstein et al. (2015) studies, our proposed conceptual model in Figure 1 is grounded in the dynamic capabilities view of the firm. The model offers some insights into enablers and mediators of supply chains implementation of sustainable practices and the resultant four broad categories of operational, financial/economic, environmental and social performance objectives. In this model are contingencies interconnectedness and influences that may result in success or failure of implementations. As Grimm et al. (2014) mentioned, the leading company have key drivers and practices for ensuring their supply chain partners meet specified sustainability standards. The various practices and methods for a concurrently sustainable and agile supply chain management are here linked in a single integrated model for increasing sustainability outcomes of industries. 
The model proposes the links amongst four constructs. These four main constructs are: agile practices, sustainable practices, operational performance objectives and sustainability performance measures. The next section discusses how these constructs are related.

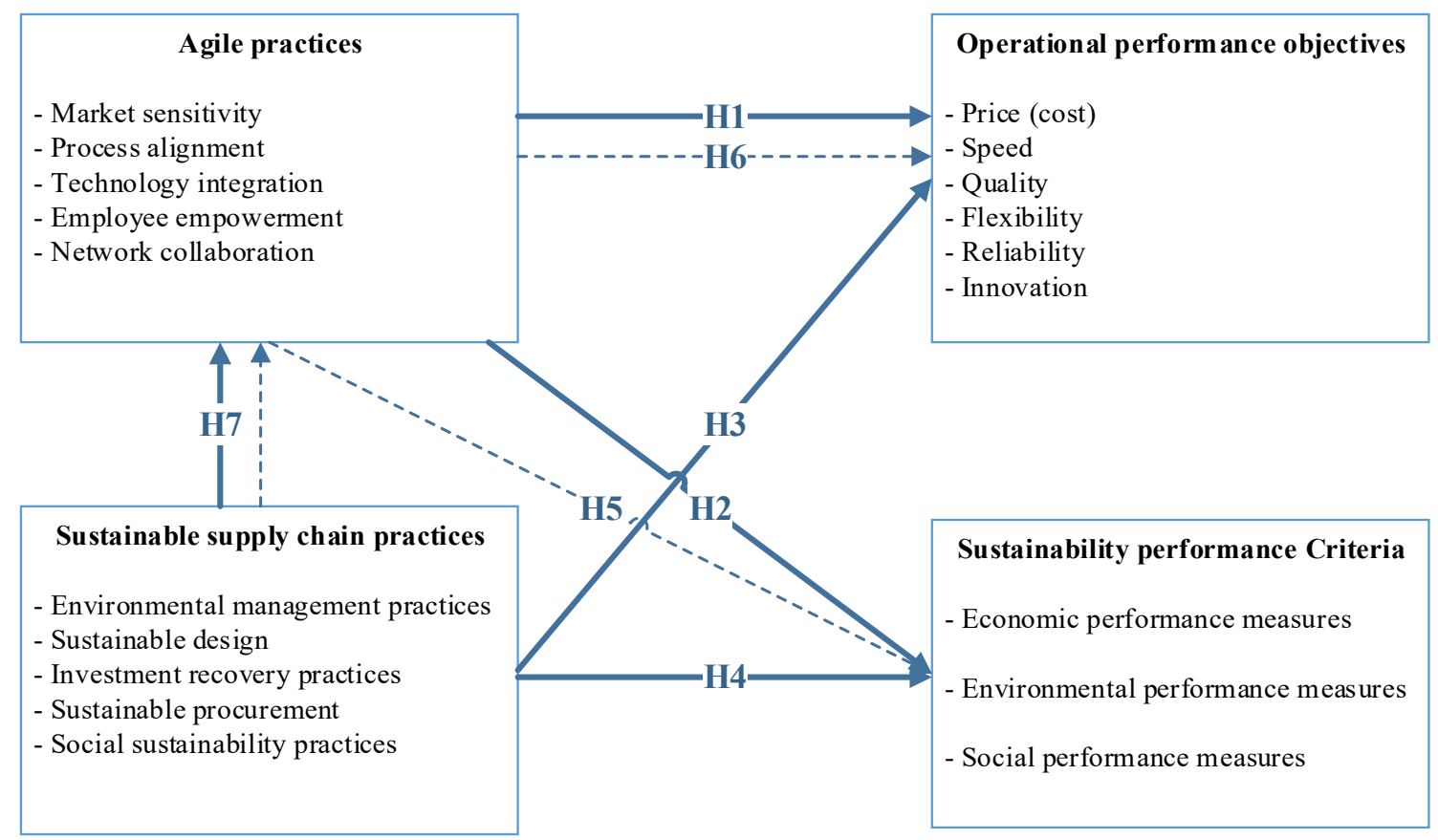

Figure 1: The proposed conceptual model

\subsection{Hypotheses development}

\subsubsection{The influence of agile methods on organisational performance criteria}

Previous studies have established that agile practices have positive and direct impacts on financial performance measures and operational performance measures (Tse et al., 2016; Eckstein et al., 2015; Yusuf et al., 2014; de Groote and Marx, 2013; Blome et al., 2013). Thus, while there has been some progress made concerning the links between agile practices and economic sustainability measures. There is no work done on the impacts of agility on social and environmental sustainability measures and yet, according to Gligor et al (2016) and Dubey et al (2015), social and environmental sustainability practices are evolving as part of the range of activities of the agile operations. In fact, recently, Ciccullo et al. (2018) identified a lack of empirical study examining the influence of agile practices on the extent to which organisations could translate sustainability practices into sustainability performance. 
Therefore, the interaction between agile practices, sustainability practices, operational performance and sustainability performance require further investigation.

The ability to share information across the supply chain will minimise waste, thereby positively influencing environmental performance (Cabral et al., 2012). In the same way, working together collaboratively with suppliers for sustainable procurement and product development has been shown to reduce usage of hazardous materials in production (Zhu and Sarkis, 2007). As Large and Thomsen (2011) demonstrated, improved knowledge transfer helps suppliers to eliminate waste, minimise pollution and emission, so enhancing companies' reputation and increasing environmental performance. As resources are increasingly becoming scarce, using advanced technology, as Yusuf et al (2014) contended, will reduce energy, water and raw materials used in manufacturing. In this, therefore, some of the established agility attributes of information and knowledge management, partnership and collaboration (Yusuf et al, 2014) can be linked to sustainability performance. We thus hypothesise that:

H1: Agile practices have a positive effect on sustainability performance.

H2: Agile practices have a positive effect on operational performance objectives

\subsubsection{The effect of sustainable supply chain practices on operational performance objectives and sustainability performance}

Sustainability performance measures are indicators of how successful the implementation of sustainability practices in an organisation (Paulraj et al., 2017; Marshall et al., 2015; Morali and Searcy, 2013). The measures indicate the degree to which sustainability practices have led to overall organisational performance. In addition to the economic performance, increasing number of companies now consider social and environmental sustainability performance as a competitive advantage (McWilliams and Siegel, 2001; McKinsey, 2013). In fact, existing literature has linked adoption of sustainability practices to cost, differentiation and innovation strategies (Crittenden et al., 2011; Orsato, 
2006; Porter and van der Linde, 1995; Orlitzky et al., 2011; Dangelico and Pujari, 2010; Prajogo et al., 2014). Prajogo et al. (2014) in particular suggested that the effective development of green and social products relates to differentiation strategies whilst, according to Orsato (2006), environmental sustainability practices can lead to cost savings. Klassen and Vereecke (2012) stressed that social and environmental sustainability are means for improving innovation whereas Christmann (2000) contended that the higher a firm's level of innovation in pollution prevention technologies, the larger the cost advantage it gains from environmental sustainability practices. Therefore, sustainability practices can result in better operational performance objectives of innovation, cost, quality and reliability.

Hart $(1995,2000)$ argued that environmental opportunities in the future would become a major source of revenue growth and competitive advantage to organisations. Extending this viewpoint, one can argue that, sustainability strategies, when successfully deployed, provide organisations with competitive advantage through, for example, environmentally differentiating products (and or markets) relative to the competition. Such practices as pollution prevention and control, waste minimisation and efficient use of resources or the broader corporate social responsibility initiatives should bring about diminished impacts of the operations of a firm on the environment and increased social and reputational capital. The implementation of sustainability practices therefore can result in better sustainability performance objectives.

In light of the above, the following hypotheses are thus proposed:

H3: Sustainable supply chain practices have positive effects on operational performance objectives.

H4: Sustainable supply chain practices have positive effects on sustainability performance objectives.

\subsubsection{Mediating roles of agile capabilities and the effects of sustainability practices on agile practices}


Several enabling factors can help in sustainable supply chain practices (Esfahbodi et al., 2016; Song et al., 2016; Huq et al., 2016; Luthra et al., 2016). Many of these enablers are closely aligned with agile methods and practices (Gunasekaran et al., 2018). Agile approaches focus on people, technology that works well, working with customers and adapting to change. It is difficult to implement sustainability practices successfully without a robust understanding of, involvement with, and knowledge of customers and other stakeholders. The market sensing capability of an agile organisation can help in understanding the expectations of customers whilst the lack of sensing capability could render sustainability initiatives unsuccessful (Wu et al., 2016a). As insights from customers can help shape platforms that create maximum return for organisations, agile organisations with market sensing capabilities can quickly leverage on the understanding of customers and information technology to develop sustainable supply chain practices. Collaboration across supply networks and multistakeholder partnerships are also indirect capabilities for advancing sustainable objectives in industries. Sustainability issues are more challenging and complex to tackle alone (Chen et al., 2017). Collaborative network capabilities will increase the influence of sustainable supply chain practices by extending the reach, pooling resources and avoid conflicting communication (Jadhav et al., 2018). Collaborative practices provide a way for supply chain members with fewer resources to take actions and contribute to advance sustainable supply chain practices. Collaboration with suppliers on sustainability issues, for example, can foster product innovation leading to new added features to existing products and even newly developed ones. The combination of market sensing and network collaborative dimensions of agility facilitate sustainability practices. Further, whilst sustainability practices are direct sources of competitiveness on their own, their performance impacts are enhanced when facilitated or mediated through agile practices. Therefore, we can hypothesise that:

H5: Agile practices mediate the relationships between sustainable supply chain practices and sustainability performance

H6: Agile practices mediate the relationships between sustainable supply chain practices and operational performance objectives. 
Further and following on from above, agile practices mediate sustainability practices because the later set of practices influence and impact on the former ones. For example, the capacity to design and create new sustainable products in response to customer requirements can result in the company developing agile capabilities. Thus, as sustainable supply chain practices induce process and product innovations that contribute to the overall agility of organisations, it can be stated that:

H7: Sustainable supply chain practices have positive effects on agile practices.

\subsection{Research methodology}

\subsection{Survey development and data collection}

The study follows a positivist epistemological position, in that, the social world exists externally, and its properties should be measured through objective approaches and not subject to scope of interpretation (Easterby-Smith et al., 2018; Bell et al., 2018). The positivism paradigm employed was survey research strategy (Dillman et al., 2014). Survey research is suitable for gathering unique and rich empirical data from a large population size (Wilson, 2014) and because it involves developing and testing hypotheses, it is considered a deductive approach. After undertaking a review of the literature on agility and sustainability in supply chains, four constructs were identified. These constructs include agility practices, sustainable supply chain practices, operational performance objectives and sustainability performance measures.

A questionnaire was developed around the constructs. Further, multiple items were used for the measurement of each construct - the scales were developed in accordance with the procedure suggested by Pallant (2013) for developing measures. The questionnaire survey involved five-point Likert scale questions, which are important measures for defining the interactions between the practices and performance measures. 
As these practices and performance measures were objective and not being inferred subjectively through social construction (Easterby-Smith et al., 2018), a mixed-mode approach of data collection was used in accordance with Dillman et al., (2014). That is, both mailed portal and web-based survey were adopted in collecting data. The aim was to mitigate any prejudice of using the individual method and enhancing the quality of the data beyond the single survey method while eliminating the possibility of bias (Frankfort-Nachmias and Nachmias, 2007). Based on the modified version of Dillman et al. (2014), a total design approach was used to gather data via a mailed postal and QuestionPro surveys from September to November 2018. Prior to the main data collection, a draft of questionnaire was sent to two academics and supply chain managers with strong interests in agility and sustainable manufacturing before it was distributed to the respondents. A single answer per organisation was requested. This is in line with similar studies in this area (Esfahbodi et al., 2017; Bottani, 2010; Aslam et al., 2018; Blome et al., 2014; Eckstein et al., 2015; van Hoek et al., 2001).

Given the fact that the consumption of resources, waste generation and implementation of sustainable supply chain practices are mostly associated with industry supply chains, the questionnaire by survey focused on UK manufacturing supply chains. The target organisations were from those involved in the extraction of crude petroleum and natural gas; mining of metal ores, coal and lignite; manufacture of coke and refined petroleum products; manufacture of chemical and chemical products; manufacture of rubber and plastic products; manufacture of steel or irons, and fabricated metal products; manufacture of electronic and electrical equipment; manufacture of machinery, motor vehicles, trailers and other transport equipment. These industries are major contributors to global carbon footprint and key consumers of natural resources and therefore, prime candidates for the study of sustainability and related practices of agility. The UK was chosen as the empirical setting for this study because of its significant share of total global manufacturing outputs and resource demands. According to a most recent report by West and Lansang (2018), the UK, in 2015, was the 9th manufacturing country in the world with an output of $\$ 244$ billion that accounted for $10 \%$ of its national output and $2 \%$ of the global manufacturing output. 
There are many challenges with respect to collection of data using simple random sampling. One drawback is that it can mean small but important parts of a population are missed altogether and the researchers cannot make confident statements about their results (Easterby-Smith et al., 2018). Another problem is difficulty in gaining access to senior executives. Other issues include a lack of knowledge of sustainability concerns among potential recipients of the questionnaires. Therefore, to avoid these problems, we employed convenience sampling. The convenience sampling enabled us to select sample units based on how easily accessible they are. Following other similar key informant-based research studies (Aslam et al., 2018; Esfahbodi et al., 2017; Yusuf et al., 2013), the objective was to find the right person in the organisation who would be able to respond to all of the questions about agility, sustainability and performance. For this reason, managing directors, Chief executive officers, Plant managers, Directors, Logistics managers, Operations managers, Sales managers, Supply chin managers, and Industrial waste managers and Procurement managers were targeted. These respondents consisted of highly skilled and knowledgeable supply chain professionals who play important roles in their organisations.

A total of nine hundred and forty-five (945) questionnaires were mailed out to our samples taken from financial analysis made easy (FAME) database and subsea oil and gas directory. A cover letter together with return stamped envelope were enclosed in the postal mail to encourage potential recipients to return the questionnaires. The survey tool was also uploaded onto the web-based QuestionPro and made visible only to respondents chosen from the sample organisations. The internet-based survey provides greater degrees of accuracy and minimises missing values (Creswell, 2014). Non-respondents were followed up two weeks after the initial mail with a reminder email and telephone calls and seven weeks later, extra questionnaires were resent to improve response rate as suggested by Frankfort-Nachmias and Nachmias (2007). In the end, 346 companies completed and returned the questionnaire, representing a response rate of $36.6 \%$. 
Following Hair et al. (2010, p. 55) suggestions, 35 incomplete responses were removed from the analysis. A total of 311 usable responses were fully completed and used in the analysis that follows.

\subsection{Non-response bias}

The non-response bias was investigated using the approach recommended by Armstrong and Overton (1977, p. 401), comparing early and late respondents as a proxy for non-respondents (Fullerton et al., 2014). The early respondents $(n=136)$ were completed before the reminder email and telephone calls was made, and these were categorised as early wave, whilst those respondents $(n=175)$ that returned the questionnaire after the email and telephone calls reminder formed the late wave. The independentsamples t-test was conducted to compare the scores for the early and late groups. As it can be seen in Table 2, the demographic characteristics of number of employees, turnover and agility practices, result shows that there was no significant difference between the mean values of the two groups, showing the null hypothesis that there is no statistically significant difference between respondents and nonrespondents cannot be rejected. In addition, based on the two-tailed significant level and Levene's ttest presented in Table 2, there was no non-response bias.

Table 2: Independent-samples t-test external validity for non-response bias of the questionnaire

\begin{tabular}{|c|c|c|c|c|c|}
\hline Constructs & $1^{\text {st }}$ Wave & $2^{\text {nd }}$ Wave & 2 tail sig. & df & Levene's test \\
\hline No of employees & 2.87 & 2.88 & $\begin{array}{l}.961 \\
.961 \\
\end{array}$ & $\begin{array}{l}309 \\
292.121 \\
\end{array}$ & .820 \\
\hline Annual turnover & 3.49 & 3.53 & $\begin{array}{l}.916 \\
.916 \\
\end{array}$ & $\begin{array}{l}309 \\
290.848 \\
\end{array}$ & .984 \\
\hline Market sensitivity & 3.75 & 3.77 & $\begin{array}{l}.875 \\
.875\end{array}$ & $\begin{array}{l}309 \\
286.805\end{array}$ & .662 \\
\hline Process alignment & 3.75 & 3.80 & $\begin{array}{l}.679 \\
.678 \\
\end{array}$ & $\begin{array}{l}309 \\
290.785 \\
\end{array}$ & .943 \\
\hline Technology integration & 3.92 & 3.97 & $\begin{array}{l}.658 \\
.660 \\
\end{array}$ & $\begin{array}{l}309 \\
283.962 \\
\end{array}$ & .350 \\
\hline Network collaboration & 3.76 & 3.83 & $\begin{array}{l}.557 \\
.559 \\
\end{array}$ & $\begin{array}{l}309 \\
286.158\end{array}$ & .442 \\
\hline Employee empowerment & 3.32 & 3.36 & $\begin{array}{l}.721 \\
.722 \\
\end{array}$ & $\begin{array}{l}309 \\
287.712\end{array}$ & .902 \\
\hline
\end{tabular}




\subsection{The respondents' demographics}

The Table 3 shows the demographics of the respondents, including number of employees, annual turnover, and business sectors of participating organisations. The sample comprises of 311 manufacturing enterprises in the UK. The table shows that companies with less than $£ 100$ million annual turnovers constituted $51.1 \%$ of the entire respondents whilst those with less than 250 employees accounted for $56.9 \%$, indicating a business structure dominated by contractors and suppliers. The respondents are well distributed across business sectors. There are three dominant groups - extraction of crude petroleum, manufacture of chemicals and chemical products, as well as manufacture of motor vehicles - accounting for $51.4 \%$ of the total sample.

Table 3: Respondent's demographics

\begin{tabular}{|c|c|c|c|c|c|}
\hline \begin{tabular}{|l|}
$\begin{array}{l}\text { Number of the } \\
\text { employees }\end{array}$ \\
\end{tabular} & $\%$ & \begin{tabular}{|l|l|} 
Turnover \\
( Million)
\end{tabular} & $\%$ & $\begin{array}{l}\text { Industry classification (UK SIC- standard industrial } \\
\text { classification) }\end{array}$ & $\%$ \\
\hline$<100$ & 33.1 & Less than 25 & 26.7 & Extraction of crude petroleum and natural gas & 23.8 \\
\hline $101-200$ & 15.4 & $26-50$ & 12.2 & Manufacture of coke and refined petroleum products & 1.0 \\
\hline $201-300$ & 8.4 & $51-100$ & 12.2 & Manufacture of chemicals and chemicals products & 14.1 \\
\hline $301-500$ & 9.6 & $101-500$ & 25.7 & $\begin{array}{l}\text { Manufacture of Pharmaceutical products and pharmaceutical } \\
\text { preparations }\end{array}$ & 2.9 \\
\hline $501-1000$ & 11.6 & $501-750$ & 5.1 & Manufacture of machinery and equipment & 4.8 \\
\hline $1001-2000$ & 7.1 & $751-1000$ & .3 & Manufacture of steel and metal products & 7.1 \\
\hline $2001-5000$ & 8.0 & $1001-2500$ & .6 & Quarrying of building stones, limestone and iron ores & 3.2 \\
\hline \multirow[t]{6}{*}{$>5000$} & 6.8 & $3001-3500$ & .3 & Manufacture of motor vehicles & 13.5 \\
\hline & & Over 3500 & 12.2 & Manufacture of electricity & 7.4 \\
\hline & & & & Manufacture of electronic and electrical equipment & 4.2 \\
\hline & & & & Manufacture of cements & 4.5 \\
\hline & & & & Transportation & 4.8 \\
\hline & & & & Other supporting activities for oil and gas extraction & 8.7 \\
\hline
\end{tabular}

\section{Results}

The analysis of the questionnaire data was carried out using statistical packages for social science (SPSS and SPSS AMOS). This software packages is one of the most widely used for statistical analysis in social sciences. The data were analysed using statistical techniques of structural equation modelling to 
explore a set of relationships amongst independent and dependent variables. Here structural equation modelling is used as a confirmatory approach to data analysis, which tests the hypothesised model to confirm the degree to which the suggested model is consistent with the data. Such analysis specifies the direct and indirect correlation among variables (Byrne, 2016).

\subsection{Exploratory factor analysis}

Exploratory factor analysis is often used in the early stages of research to gather information about the interrelationships among a set of variables. It can also be used to reduce a large number of related variables to a more manageable number, prior to using them in the structural equation modelling (Tabachnick and Fidell, 2014). Prior to performing the exploratory factor analysis, the suitability of data for factor analysis was assessed. The inspection of the correlation matrix revealed the presence of coefficients value of 0.70 and above. The Kaiser-Meyer-Olkin value was 0.872 , exceeding the recommended value of 0.6 (Kaiser, 1974) and Bartlett's Test of Sphericity (Bartlett, 1954) reached statistical significance value of 0.000 , supporting the factorability of the correlation matrix, as displayed in table 4.1.

Principal components analysis was used as the factor extraction approach to performing exploratory factor analysis. Varimax technique of orthogonal rotation was then used (Fullerton et al., 2014), resulting in fourteen factors with eigenvalue greater than 1, explaining (see table 4.2 for details) of the variance respectively (Hair et al., 2014). Both components are showing a number of strong loadings and each item loads substantially on one component (see details in table 4.2). Loadings under 0.50 were removed as suggested by (Marshall et al., 2007). The initial 95 items were reduced to 82 items.

In sum, inspection of the factor items in Table 4.2 shows the components of agile supply chain practices. For example, component 1 represent process alignment (PA), component 7 was labelled as market sensitivity (MS), component 8 relates to employee empowerment (EE), component 11 reflected technology integration (TI), and component 14 represent network collaboration (NC). The components on sustainable supply chain practices include component 2: sustainable procurement (SPr); component

3 social sustainability practices (SSP); component 5 sustainable design (SD); component 9: 
Environmental management practices (EMP), component 13 investment recovery (IR). The factors on dependent variable are: component 4; environmental performance (EP); component 6 operational performance objectives (SP); component 10 social performance (OPO) and component 12 financial performance (FP).

Table 4.1 KMO and Bartlett's Test

\begin{tabular}{||c|c|c|}
\hline \multicolumn{2}{|c|}{ Kaiser-Meyer-Olkin Measure of Sampling Adequacy. } & .872 \\
\hline \hline \multirow{3}{*}{ Bartlett's Test of Sphericity } & 35885.440 & 2657.340 \\
\cline { 2 - 3 } & 3321 & 630 \\
\cline { 2 - 3 } & .000 & .000 \\
\hline
\end{tabular}

Table 4.2 Exploratory factor analysis: factor loadings for explanatory variables

\begin{tabular}{|c|c|c|c|c|c|c|c|c|c|c|c|c|c|c|c|}
\hline \multirow{3}{*}{$\begin{array}{l}\text { Item } \\
\#\end{array}$} & \multicolumn{14}{|c|}{ Factor loadings } & \multirow{2}{*}{$\begin{array}{l}\text { Extracted } \\
\text { Communalities }\end{array}$} \\
\hline & 1 & \begin{tabular}{|l|}
2 \\
\end{tabular} & 3 & 4 & 5 & 6 & 7 & 8 & 9 & 10 & 11 & 12 & 13 & 14 & \\
\hline & SSP & $\mathrm{NC}$ & EE & EP & $\mathrm{SPr}$ & SD & PA & TI & MS & SP & EMP & OPO & FP & IR & h2 \\
\hline spr1 & & & & & 0.892 & & & & & & & & & & .838 \\
\hline spr4 & & & & & 0.893 & & & & & & & & & & .828 \\
\hline spr5 & & & & & 0.893 & & & & & & & & & & 8.844 \\
\hline spr6 & & & & & 0.899 & & & & & & & & & & .840 \\
\hline spr8 & & & & & 0.899 & & & & & & & & & & .848 \\
\hline spr9 & & & & & 0.857 & & & & & & & & & & .799 \\
\hline ep1 & & & & 0.917 & & & & & & & & & & & .872 \\
\hline$\overline{\mathrm{ep} 2}$ & & & & 0.924 & & & & & & & & & & & .885 \\
\hline ep3 & & & & 0.909 & & & & & & & & & & & .883 \\
\hline ep4 & & & & 0.896 & & & & & & & & & & & .872 \\
\hline ep5 & & & & 0.909 & & & & & & & & & & & .879 \\
\hline ep6 & & & & 0.884 & & & & & & & & & & & .834 \\
\hline fp6 & & & & & & & & & & & & & 0.799 & & .690 \\
\hline fp7 & & & & & & & & & & & & & 0.838 & & .742 \\
\hline fp8 & & & & & & & & & & & & & 0.931 & & .883 \\
\hline fp9 & & & & & & & & & & & & & 0.891 & & .820 \\
\hline fp10 & & & & & & & & & & & & & 0.916 & & .875 \\
\hline emp1 & & & & & & & & & & & 0.885 & & & & .842 \\
\hline emp2 & & & & & & & & & & & 0.898 & & & & .865 \\
\hline emp4 & & & & & & & & & & & 0.916 & & & & .873 \\
\hline emp6 & & & & & & & & & & & 0.929 & & & & .884 \\
\hline emp7 & & & & & & & & & & & 0.922 & & & & .872 \\
\hline pa1 & & & & & & & 0.977 & & & & & & & & .976 \\
\hline pa2 & & & & & & & 0.978 & & & & & & & & .972 \\
\hline pa4 & & & & & & & 0.978 & & & & & & & & .979 \\
\hline pa6 & & & & & & & 0.982 & & & & & & & & .981 \\
\hline pa7 & & & & & & & 0.981 & & & & & & & & .981 \\
\hline
\end{tabular}




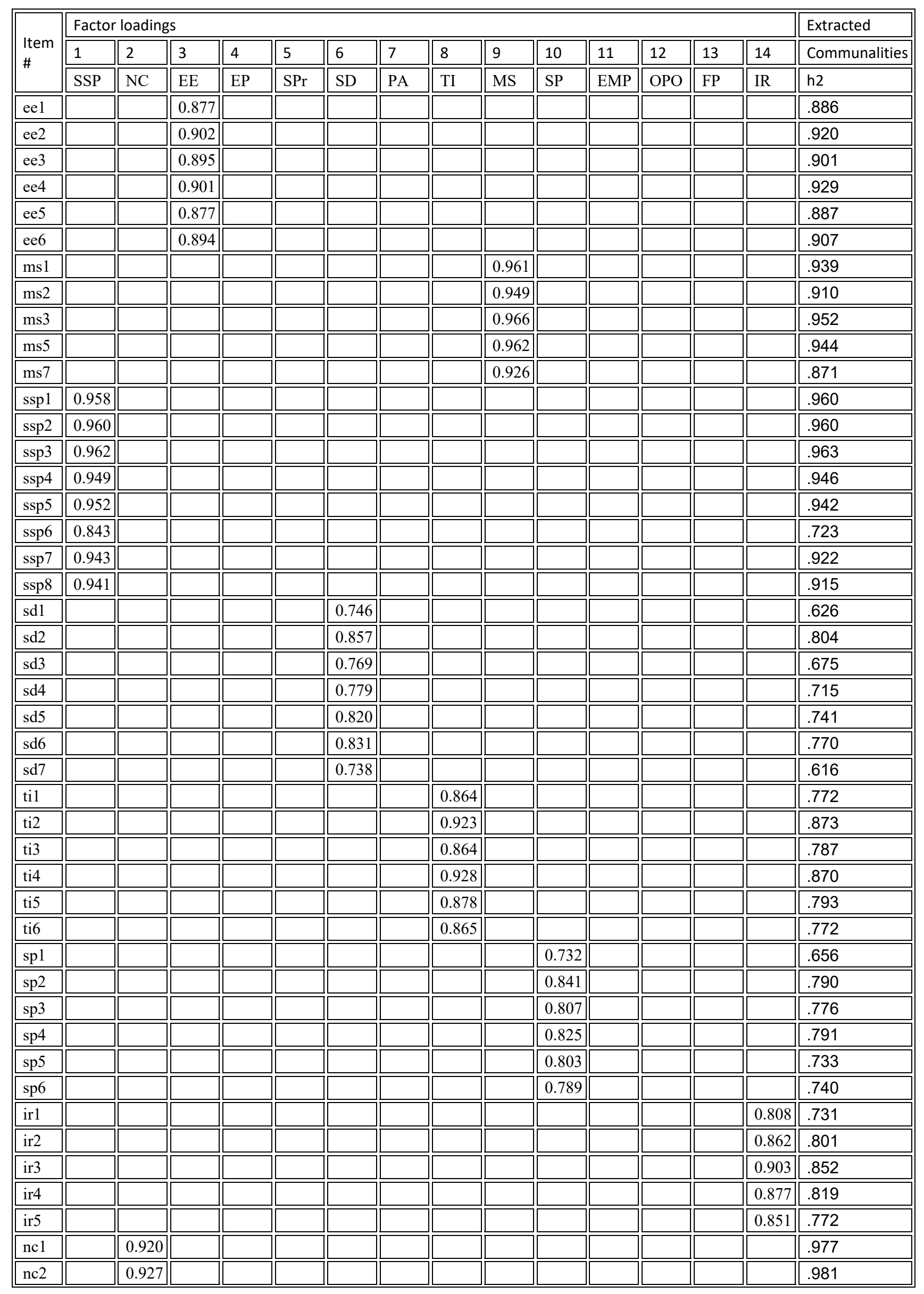




\begin{tabular}{|c|c|c|c|c|c|c|c|c|c|c|c|c|c|c|c|}
\hline \multirow{3}{*}{$\begin{array}{l}\text { Item } \\
\#\end{array}$} & \multicolumn{14}{|c|}{ Factor loadings } & \multirow{2}{*}{$\begin{array}{l}\text { Extracted } \\
\text { Communalities } \\
\end{array}$} \\
\hline & 1 & 2 & 3 & 4 & 5 & 6 & 7 & 8 & 9 & 10 & 11 & 12 & 13 & 14 & \\
\hline & SSP & $\mathrm{NC}$ & EE & EP & SPr & SD & PA & TI & MS & SP & EMP & OPO & FP & IR & h2 \\
\hline nc3 & & 0.914 & & & & & & & & & & & & & $\begin{array}{c}.974 \\
\end{array}$ \\
\hline nc4 & & 0.868 & & & & & & & & & & & & & .873 \\
\hline nc5 & & 0.921 & & & & & & & & & & & & & 978 \\
\hline nc6 & & 0.916 & & & & & & & & & & & & & .963 \\
\hline opo1 & & & & & & & & & & & & 0.817 & & & .769 \\
\hline opo2 & & & & & & & & & & & & 0.773 & & & .779 \\
\hline opo4 & & & & & & & & & & & & \begin{tabular}{|l|}
0.774 \\
\end{tabular} & & & .697 \\
\hline opo4 & & & & & & & & & & & & \begin{tabular}{|c|}
0.723 \\
\end{tabular} & & & .642 \\
\hline opo5 & & & & & & & & & & & & 0.802 & & & .724 \\
\hline opo6 & & & & & & & & & & & & \begin{tabular}{|c|}
0.750 \\
\end{tabular} & & & .670 \\
\hline 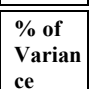 & $15.75 \%$ & $\mid 11.93 \%$ & $\mid 7.17 \%$ & $6.70 \%$ & $6.13 \%$ & $5.93 \%$ & $5.21 \%$ & $5.01 \%$ & $4.18 \%$ & $3.89 \%$ & $3.53 \%$ & $3.12 \%$ & $3.03 \%$ & $2.76 \%$ & \\
\hline
\end{tabular}

\subsection{Test of psychometric properties}

Prior to the analysis of the data, a test of reliability and validity was carried out. Reliability involves the consistency of a measure of a construct. The most commonly used indicators of internal consistency are Cronbach's alpha coefficient (Rungtusanatham et al., 2003). In line with DeVellis (2016), a good reliability should have Cronbach's alpha coefficient of a value above 0.70 . The test of reliability was done and resulting in Cronbach's values of 0.906 for entire study constructs (see table 6 for details reliability of sub-constructs). These suggest a very strong internal consistency and reliability as all alpha values are above 0.70 (DeVellis, 2016).

The confirmatory factor analysis was used to establish convergent validity and unidimensionality of constructs. The confirmatory factor analysis was performed separately for independent and dependent variables. The results show a good model fit for the independent and dependent variables as follows: independent variables normed chi-square (chi-square/degree of freedom) value of 1.336; a root means square error of approximation $($ RMSEA $)=0.033$; a goodness of fit index $(\mathrm{GFI})$ value of $\mathbf{0 . 8 2 9}$; and a comparative fit index (CFI) value of $\mathbf{0 . 9 8 2}$. whilst, dependent variables include: normed chi-square (chi-square/degree of freedom) value of 1.886; a root mean square error of approximation (RMSEA) $=$ 
0.053; a goodness of fit index (GFI) value of $\mathbf{0 . 9 0 6}$; and a comparative fit index (CFI) value of $\mathbf{0 . 9 8 5}$ were found to be adequate. The fit indices equal to or exceeded the minimum threshold value of 0.9 as recommended by (Koufteros, 1999). In addition, standard loadings were in all cases above 0.70 . Thus, support was found for the convergent validity and composite reliability in our measurement model as recommended by (Fornell and Larcker, 1981).

More so, we compared the square root of the construct's average variance extracted with the constructs correlation to established discriminant validity as suggested by (Fornell and Larcker, 1981). Table 5 indicate the square root of the average variance extracted as bold in the diagonal. As can be seen, the entire construct's correlations were found to be less than the square root of the average variance extracted for individual construct. As such, there is support for discriminant validity.

Furthermore, we used procedural approach to reduce the potential for common method bias since both dependent and independent variables were obtained from the same source. The respondents to our questionnaire survey were mostly senior managers with high level of skills and knowledge about agility and sustainability, which tends to minimise common method bias. More so, we separated the measures over the length of the survey instrument and guaranteeing participants that their responses would be kept anonymous - this also reduced common bias (Podsakoff et al., 2003) as a result of decreased motivation. Financial analysis made easy (FAME) database was used to check consistency over demographic variables and performance criteria to further reduce the threat of common method bias. In the same way, Harman's one-factor test was carried out (Podsakoff et al., 2003). A factor analysis was also conducted on the variables and it did not yield a single-factor solution. In addition, the validity and reliability test (Tables 5a and 5b) plus whole model fit (Table 6) show strong support for the suitability of the model constructs.

Table 5a: Correlation matric, convergent and discriminant validity test of the constructs (second order model)

\begin{tabular}{|c|c|c|c|c|c|c|c|}
\hline & $\alpha$ & $\mathbf{C R}$ & AVE & $\begin{array}{l}\text { Model } \\
1\end{array}$ & $\begin{array}{l}\text { Model } \\
2\end{array}$ & $\begin{array}{l}\text { Model } \\
\mathbf{3}\end{array}$ & $\begin{array}{l}\text { Model } \\
4\end{array}$ \\
\hline Agile practices & 0.884 & 0.994 & 0.850 & 0.922 & & & \\
\hline Sustainable supply chain practices & 0.864 & 0.991 & 0.776 & $.559^{* *}$ & 0.881 & & \\
\hline Operational performance & 0.909 & 0.899 & 0.598 & $.639^{* *}$ & $.517^{* *}$ & 0.773 & \\
\hline
\end{tabular}


**. Correlation is significant at the 0.01 level (2-tailed).

$\alpha$ construct reliabilities

Square root of Average Variance Extracted (AVE) shown as bold in diagonal 
Table 5b: Correlation matric, convergent and discriminant validity test of the constructs (first order model)

\begin{tabular}{|c|c|c|c|c|c|c|c|c|c|c|c|c|c|c|c|c|}
\hline Sub-constructs & CR & AVE & $\mathbf{E E}$ & MS & PA & TI & $\mathrm{NC}$ & EMP & SPr & SD & IR & SSP & SP & EP & PA & FP \\
\hline Employee empowerment (EE) & .958 & .794 & .891 & & & & & & & & & & & & & \\
\hline Market sensitivity (MS) & .980 & .908 & $.231^{* *}$ & .953 & & & & & & & & & & & & \\
\hline Process alignment (PA) & .991 & .959 & $.543^{* *}$ & $.314^{* *}$ & .979 & & & & & & & & & & & \\
\hline Technology integration (TI) & .957 & .787 & $.455^{* *}$ & $.354^{* *}$ & $.557^{* *}$ & .887 & & & & & & & & & & \\
\hline Network collaboration (NC) & .967 & .830 & $.395^{* *}$ & $.265^{* *}$ & $.555^{* *}$ & $.528^{* *}$ & .911 & & & & & & & & & \\
\hline Environmental management practices (EMP) & .960 & .829 & $.127^{*}$ & $.118^{*}$ & .109 & $.154^{* *}$ & $.161^{* *}$ & .910 & & & & & & & & \\
\hline Sustainable procurement (SPr) & .958 & .790 & $.258^{* *}$ & $.393^{* *}$ & $.283^{* *}$ & $.422^{* *}$ & $.241^{* *}$ & .067 & .889 & & & & & & & \\
\hline Sustainable Design (SD) & .922 & .628 & $.244^{* *}$ & $.261^{* *}$ & $.209^{* *}$ & $.279^{* *}$ & $.262^{* *}$ & $.114^{*}$ & $.546^{* *}$ & .792 & & & & & & \\
\hline Investment recovery (IR) & .935 & .741 & $.266^{* *}$ & $.213^{* *}$ & $.313^{* *}$ & $.317^{* *}$ & .105 & $.165^{* *}$ & $.121^{*}$ & .104 & .861 & & & & & \\
\hline Social sustainability practices (SSP) & .984 & .882 & $.338^{* *}$ & $.268^{* *}$ & $.441^{* *}$ & $.443^{* *}$ & $.269^{* *}$ & $.132^{*}$ & $.325^{* *}$ & $.294^{* *}$ & $.334^{* *}$ & .939 & & & & \\
\hline Social performance (SP) & .914 & .640 & $.457^{* *}$ & $.430^{* *}$ & $.558^{* *}$ & $.490^{* *}$ & $.457^{* *}$ & $.187^{* *}$ & $.354^{* *}$ & $.465^{* *}$ & $.372^{* *}$ & $.371^{* *}$ & .800 & & & \\
\hline Environmental performance (EP) & .965 & .822 & $.446^{* *}$ & $.387^{* *}$ & $.481^{* *}$ & $.561^{* *}$ & $.425^{* *}$ & $.178^{* *}$ & $.386^{* *}$ & $.399^{* *}$ & $.323^{* *}$ & $.641^{* *}$ & $.581^{* *}$ & .907 & & \\
\hline Operational performance objectives (OPO) & .899 & .599 & $.327^{* *}$ & $.380^{* *}$ & $.568^{* *}$ & $.399^{* *}$ & $.359^{* *}$ & $.162^{* *}$ & $.360^{* *}$ & $.278^{* *}$ & $.235^{* *}$ & $.438^{* *}$ & $.521^{* *}$ & $.517^{* *}$ & .774 & \\
\hline Financial performance $(\mathrm{FP})$ & .943 & .768 & $.384^{* *}$ & $.559^{* *}$ & $.511^{* *}$ & $.449^{* *}$ & $.376^{* *}$ & $.275^{* *}$ & $.375^{* *}$ & $.372^{* *}$ & $.313^{* *}$ & $.530^{* *}$ & $.611^{* *}$ & $.679^{* *}$ & $.721^{* *}$ & .876 \\
\hline
\end{tabular}

**. Correlation is significant at the 0.01 level (2-tailed).

* Correlation is significant at the 0.05 level (2-tailed).

Square root of Average Variance Extracted (AVE) shown as bold in diagonal 
Table 6: Results of confirmatory factor analysis

\begin{tabular}{|c|c|c|c|c|}
\hline Items \# & Scale items & $\begin{array}{l}\text { Standardised } \\
\text { item loadings }\end{array}$ & $\mathrm{R}^{2}$ & t-value \\
\hline \multicolumn{5}{|c|}{$\begin{array}{l}\text { Entire constructs Cronbach's } \quad \alpha=.909 \\
\end{array}$} \\
\hline Agile practices & \multicolumn{4}{|c|}{ Second-order construct consisting five main dimensions; Cronbach's $\alpha=(.884)$} \\
\hline Process alignment (PA) & Cronbach's $\alpha=(.994), \mathrm{CR}=(0.991), \mathrm{AVE}=(0.959)$ & & & \\
\hline PA1 & Decentralised decision making & .983 & .966 & 9.043 \\
\hline PA2 & Cross functional teams & .982 & .964 & 9.105 \\
\hline PA4 & Information accessible to employees & .990 & .981 & 7.040 \\
\hline PA6 & Concurrent execution of activities & .984 & .969 & 9.254 \\
\hline PA7 & Quality over product life & .984 & .969 & a \\
\hline \multirow{7}{*}{$\begin{array}{l}\text { Technology integration } \\
\text { (TI) }\end{array}$} & \multicolumn{4}{|l|}{ Cronbach's $\alpha=(.950), \mathrm{CR}=(0.957), \mathrm{AVE}=(0.787)$} \\
\hline & Flexible production technology & .836 & .699 & $\mathrm{a}$ \\
\hline & Leadership in the use of current technology & .928 & .861 & 8.885 \\
\hline & Skill and knowledge enhancing technologies & .848 & .720 & 10.997 \\
\hline & Technology awareness & .931 & .867 & 8.706 \\
\hline & First time right design & .843 & .710 & 11.064 \\
\hline & Virtual enterprise & .841 & .706 & 11.089 \\
\hline $\begin{array}{l}\text { Network collaboration } \\
\text { (NC) }\end{array}$ & \multicolumn{4}{|l|}{ Cronbach's $\alpha=(.991), \mathrm{CR}=(0.967), \mathrm{AVE}=(0.830)$} \\
\hline $\mathrm{NC1}$ & Close relationship with customer & .991 & .983 & $-\mathrm{a}$ \\
\hline NC2 & Trust-based relationship with customers/suppliers & .994 & .989 & 7.586 \\
\hline NC3 & Multi-venturing capabilities & .982 & .964 & 10.972 \\
\hline NC4 & Rapid partnership formation & .906 & .821 & 12.205 \\
\hline NC5 & Teams across company borders & .986 & .973 & 10.495 \\
\hline NC6 & Enterprise integration & .977 & .956 & 11.285 \\
\hline $\begin{array}{l}\text { Employee empowerment } \\
\text { (EE) }\end{array}$ & \multicolumn{4}{|l|}{ Cronbach's $\alpha=(.978), \mathrm{CR}=(0.958), \mathrm{AVE}=(0.794)$} \\
\hline EE1 & Employee satisfaction & .910 & .828 & 9.989 \\
\hline EE2 & Learning organisation & .936 & .876 & 10.388 \\
\hline EE3 & Workforce skill upgrade & .934 & .872 & 8.707 \\
\hline EE4 & Multi-skilled and flexible people & .962 & .926 & 10.436 \\
\hline EE5 & Continuous training and development & .935 & .875 & 10.313 \\
\hline EE6 & Culture of change & .945 & .892 & a \\
\hline Market sensitivity (MS) & \multicolumn{4}{|l|}{ Cronbach's $\alpha=(.978), \mathrm{CR}=(0.980), \mathrm{AVE}=(0.908)$} \\
\hline MS1 & Customer driven innovation & .944 & .892 & 11.544 \\
\hline MS2 & Response to changing market requirements & .918 & .842 & 7.712 \\
\hline MS3 & New product introduction & .983 & .967 & 6.063 \\
\hline MS5 & Customer satisfaction & .976 & .953 & 11.274 \\
\hline MS7 & Strategic relationship with customers and stakeholders & .904 & .816 & a \\
\hline $\begin{array}{l}\text { Sustainable supply chain } \\
\text { practices }\end{array}$ & \multicolumn{4}{|c|}{ Second-order construct consisting five main dimensions; Cronbach’s $\alpha=(.864)$} \\
\hline $\begin{array}{l}\text { Sustainable procurement } \\
\text { (SPr) }\end{array}$ & \multicolumn{4}{|l|}{ Cronbach's $\alpha=(.957), \mathrm{CR}=(0.958), \mathrm{AVE}=(0.790)$} \\
\hline SPr1 & Sustainability audit for suppliers' internal management & .891 & .795 & 10.286 \\
\hline SPr4 & Cooperation with customer for sustainable packaging & .877 & .770 & 10.584 \\
\hline SPr5 & Cooperation with suppliers for sustainability objectives & .901 & .813 & 10.022 \\
\hline SPr6 & $\begin{array}{l}\text { Providing design specification to suppliers that include } \\
\text { sustainability requirements for their process }\end{array}$ & .893 & .798 & 10.247 \\
\hline SPr8 & Supplier' ISO 14000 certification & .899 & .809 & 10.087 \\
\hline SPr9 & Multi-tiers suppliers sustainability practices evaluation & .864 & .747 & a \\
\hline Sustainable design (SD) & \multicolumn{4}{|l|}{ Cronbach's $\alpha=(.924), \mathrm{CR}=(0.922), \mathrm{AVE}=(0.628)$} \\
\hline SD1 & Cooperation with customers for eco design & .717 & .515 & 11.497 \\
\hline SD2 & $\begin{array}{l}\text { Design of products for reduced consumption of } \\
\text { materials }\end{array}$ & .869 & .755 & 9.650 \\
\hline
\end{tabular}




\begin{tabular}{|c|c|c|c|c|}
\hline Items \# & Scale items & $\begin{array}{l}\text { Standardised } \\
\text { item loadings }\end{array}$ & $\mathrm{R}^{2}$ & t-value \\
\hline SD3 & $\begin{array}{l}\text { Design of products for reuse, recycle, remanufacturing, } \\
\text { and/or recovery of materials and component parts }\end{array}$ & .769 & .591 & 11.146 \\
\hline SD4 & Design of products for easy disassembly & .808 & .654 & 10.744 \\
\hline SD5 & $\begin{array}{l}\text { Design of products to avoid or reduce use of hazardous } \\
\text { materials }\end{array}$ & .835 & .698 & 10.359 \\
\hline SD6 & Cooperation with customers for cleaner production & .723 & .523 & 11.467 \\
\hline SD7 & Design of products for reduced consumption of energy & .855 & .730 & $\mathrm{a}$ \\
\hline Investment recovery (IR) & \multicolumn{4}{|l|}{ Cronbach's $\alpha=(.931), \mathrm{CR}=(0.935), \mathrm{AVE}=(0.741)$} \\
\hline IR1 & $\begin{array}{l}\text { We used a product's materials for a basic, low value } \\
\text { purpose }\end{array}$ & .801 & .641 & $-^{\mathrm{a}}$ \\
\hline IR2 & $\begin{array}{l}\text { We are extracting a product's raw materials and using } \\
\text { them for new products }\end{array}$ & .853 & .728 & 10.143 \\
\hline IR3 & $\begin{array}{l}\text { We returned products to the performance specification } \\
\text { of the original equipment manufacturer }\end{array}$ & .907 & .823 & 8.414 \\
\hline IR4 & $\begin{array}{l}\text { We are redeploying products without the need for } \\
\text { refurbishment }\end{array}$ & .879 & .772 & 9.514 \\
\hline IR5 & We sale excess capital equipment & .834 & .695 & 10.499 \\
\hline $\begin{array}{l}\text { Social sustainability } \\
\text { practices (SSP) }\end{array}$ & \multicolumn{4}{|l|}{ Cronbach's $\alpha=(.986), \mathrm{CR}=(0.984), \mathrm{AVE}=(0.882)$} \\
\hline SSP1 & We established health and safety management system & .988 & .978 & 8.995 \\
\hline SSP2 & We support community involvement and development & .985 & .979 & 8.923 \\
\hline SSP3 & Worker's Skills and capabilities development & .989 & .978 & 9.147 \\
\hline SSP4 & Respect for people rights & .968 & .936 & 11.361 \\
\hline SSP5 & $\begin{array}{l}\text { Provide training for emergency preparedness program } \\
\text { to employees, suppliers and community }\end{array}$ & .963 & .928 & 11.500 \\
\hline SSP6 & We guarantee worker's health and safety at work & .792 & .627 & 12.327 \\
\hline SSP7 & $\begin{array}{l}\text { We make products that protect consumers' health and } \\
\text { safety }\end{array}$ & .924 & .854 & 12.021 \\
\hline SSP8 & $\begin{array}{l}\text { We support and promote health situation in the } \\
\text { community }\end{array}$ & .920 & .847 & $-{ }^{\mathrm{a}}$ \\
\hline $\begin{array}{l}\text { Environmental } \\
\text { management practices } \\
(\text { EMP) }\end{array}$ & \multicolumn{4}{|l|}{ Cronbach's $\alpha=(.960), \mathrm{CR}=(0.960), \mathrm{AVE}=(0.829)$} \\
\hline EMP1 & $\begin{array}{l}\text { We monitor our suppliers' commitment to } \\
\text { sustainability improvement }\end{array}$ & .883 & .780 & 10.607 \\
\hline EMP2 & $\begin{array}{l}\text { Commitment of sustainability practices from senior } \\
\text { manager }\end{array}$ & .901 & .811 & 10.199 \\
\hline EMP4 & We helped our suppliers obtain ISO 14001 certification & .916 & .838 & 9.725 \\
\hline EMP6 & $\begin{array}{l}\text { Support for sustainability practices from mid-level } \\
\text { managers }\end{array}$ & .928 & .861 & 9.187 \\
\hline EMP7 & $\begin{array}{l}\text { We frequently visit our suppliers' premises to help } \\
\text { improve their eco innovation }\end{array}$ & .916 & .838 & $-^{\mathrm{a}}$ \\
\hline $\begin{array}{l}\text { Operational performance } \\
\text { objectives (OPO) }\end{array}$ & \multicolumn{4}{|l|}{ Cronbach's $\alpha=(.909), \mathrm{CR}=(0.899), \mathrm{AVE}=(0.598)$} \\
\hline OPO1 & Costs & .843 & .711 & $\mathrm{a}$ \\
\hline OPO2 & Flexibility & .862 & .743 & 9.189 \\
\hline OPO4 & Quality & .782 & .611 & 10.686 \\
\hline OPO4 & Innovation & .742 & .550 & 11.083 \\
\hline OPO5 & Reliability & .763 & .582 & 10.892 \\
\hline OPO6 & \begin{tabular}{|l|l} 
Speed &
\end{tabular} & .750 & .562 & 11.012 \\
\hline Sustainability performance & \multicolumn{4}{|c|}{ Second-order construct consisting three main dimensions, Cronbach's $\alpha=(.860)$} \\
\hline Financial performance $(\mathrm{FP})$ & Cronbach's $\alpha=(.932), \mathrm{CR}=(0.943), \mathrm{AVE}=(0.768)$ & & & \\
\hline FP6 & Increase in rate of return on investment & .724 & .524 & $\ldots$ \\
\hline FP7 & Growth in market share & .773 & .597 & 11.531 \\
\hline FP8 & Increase in sale turnover & .928 & .860 & 8.415 \\
\hline FP9 & Increase in profitability & .905 & .818 & 9.552 \\
\hline FP10 & Increase in customers' satisfaction & .937 & .878 & 7.784 \\
\hline
\end{tabular}




\begin{tabular}{|c|c|c|c|c|}
\hline Items \# & Scale items & $\begin{array}{l}\text { Standardised } \\
\text { item loadings }\end{array}$ & $\mathrm{R}^{2}$ & t-value \\
\hline Social performance (SP) & Cronbach's $\alpha=(.927), \mathrm{CR}=(0.914), \mathrm{AVE}=(0.640)$ & & & \\
\hline SP1 & Improved overall stakeholders' welfare & .755 & .569 & $\mathrm{a}$ \\
\hline SP2 & Improved health and safety of the community & .857 & .735 & 9.936 \\
\hline SP3 & Improved health and safety of workers & .852 & .725 & 10.051 \\
\hline SP4 & Improved community involvement and development & .873 & .762 & 9.539 \\
\hline SP5 & Improved awareness or protection of human rights & .801 & .641 & 10.839 \\
\hline SP5 & Improved product responsibility & .805 & 647 & 10.792 \\
\hline $\begin{array}{l}\text { Environmental } \\
\text { performance (EP) }\end{array}$ & Cronbach's $\alpha=(.968), \mathrm{CR}=(0.965), \mathrm{AVE}=(0.822)$ & & & \\
\hline EP1 & Reduction in solid waste and waste water & .981 & .963 & a \\
\hline EP2 & Reduction of air emission & .988 & .976 & 4.289 \\
\hline EP3 & Decrease in use of natural resources & .880 & .775 & 11.857 \\
\hline EP4 & $\begin{array}{l}\text { Decrease in consumption for hazardous/harmful/toxic } \\
\text { materials }\end{array}$ & .835 & 697 & 12.059 \\
\hline EP5 & Decrease in frequency for environmental accidents & .817 & .668 & 12.108 \\
\hline EP6 & $\begin{array}{l}\text { Improvement of an enterprise's environmental } \\
\text { situation }\end{array}$ & .786 & .619 & 12.174 \\
\hline
\end{tabular}

*** all significant to $\mathrm{P}<0.000$

a indicates a parameter that was fixed at 1.000

$\mathrm{n}=311$, Estimation Method $=$ Maximum Likelihood.

Model fit indexes: $\mathrm{CMIN} / \mathrm{DF}=1.792 ; \mathrm{CFI}=0.931 ; \mathrm{TLI}=0.927 ; \mathrm{IFI}=0.931 ;$ and $\mathrm{RMSEA}=0.051$

\subsection{Assessing the fit of the model}

After the model has been specified and then estimated, there is the need to determine whether it is a good model fit to run structural equation modelling. The key factor of a good model is the fit among covariance matrix. One very rough rule of thumb, however, directly related to the $x^{2}$ value is that a good-fitting model may be indicated when the ratio of the $x^{2}$ to the degree of freedom is less than 2 . Broadly, the following type of fit indexes were assessed (Hair et al., 2014; Tabachnick and Fidell, 2014). The normed fit index (NFI), which compares the $x^{2}$ value of the estimated model to the $x^{2}$ value of the independent model. The non-normed fit index (NNFI) which is an adjustment to the NFI integrating the degree of freedom in the model, the incremental fit index (IFI) which addresses the problem of the large variability in the NNFI and the comparative fit index (CFI) that assesses fit relative to other models. Other fit indexes include the root mean square error of approximation (RMSEA); the goodness-of-fit index (GFI), and many others (Hair et al., 2014; Tabachnick and Fidell, 2014). The suggested values for CFI, IFI, and TLI must be above 0.90 or close to 1.00 (Byrne, 2016). Whereas RMSEA values for good model should be less than or equal to 0.06 (Hu and Bentler, 1999), in this study, the assessment of model fit shows a normed chi-square (chi-square/degree of freedom) value of 
$\left(X^{2}=1.792, \mathrm{P}<0.05\right)$; CFI value of 0.931 ; TLI value of 0.927 ; IFI value of 0.931 and RMSEA value of 0.051 . This indicates that the model provides a good model fit. As well, the fourteen components give a good structure in which to continue the structural equation modelling. The standardised values for the item loadings and the t-values for all the scale items are shown in table 6.

\subsection{Hypotheses testing}

Even though we have found some support for the hypothesised model, post hoc model modifications were carried out in an attempt to develop a better fitting model. Based on the theoretical importance, seven residual covariances were estimated (residual covariance among: information accessible to employees and team across company borders; concurrent execution of activities and quality over product life; monitor supplier operations and leadership commitment; provision of design specification to supplier and ISO 14000 certification; and increase in profitability and increase in customer satisfaction). The model was significantly improved with the addition of these paths. The assessment of model fit shows a normed chi-square (chi-square/degree of freedom) value of $\left(X^{2}=1.597, P<0.001\right)$; CFI value of 0.947 ; TLI value of 0.945 ; IFI value of 0.947 and RMSEA value of 0.044 . These indicate adequate fit (see details in Table 7).

The Table 7 indicates that greater sustainable supply chain practices predict agile practices (standardised coefficient $=0.327, p<0.001$ ). In the same vein, increased sustainability performance was predicted by more agile practices (standardised coefficient $=0.407, p<0.001$ ). In addition, increasing sustainable supply chain practices has a significant positive impacts on sustainability performance (standardised coefficient $=.750, p<0.001$ ). Moreover, operational performance objectives improved as agile practices improved (standardised coefficient $=0.537, p<0.001$ ). Similarly, rise in sustainable supply chain practices resulted in growth in operational performance (standardised coefficient $=0.205, p<0.001)$.

The importance of the intervening variables was examined using tests of indirect effects through Sobel test (Sobel, 1982 quoted in Tabachnick and Fidell, 2014) in order to test the hypotheses H5 and H6. The Sobel test method of examining intervening variables is more powerful than mediating variable 
approach (MacKinnon et al., 2002). The Table 8 displays the results of (H5) mediating influence of agile practices on the relationship between sustainable supply chain practices and sustainability performance and (H6) mediating influence of agile practices on the relationship between sustainable supply chain practices and operational performance. The results show that sustainable supply chain initiatives, when mediated through agile practices, lead to a much better sustainability performance outcomes $(\beta=0.135, P>0.147)$, and higher level of operational performance $(\beta=0.172, P>0.103)$. The $P$ values in both cases $(P>0.103 ; P>0.147)$ are greater than 0.05 indicating there is mediation. In addition, CFI and NFI exceeded 0.90 as recommended by Byrne (2016), RMSEA is below 0.06 (Hu and Bentler, 1999), and the normed chi-square (chi-square/degree of freedom) value of $X^{2}$ is less than 2 (Tabachnick and Fidell, 2014) all indicating a strong case of mediation. The totality of these statistics suggests the amplification effects of agile practices on the transformation of sustainable supply chain implementation initiatives into sustainability performance of industries. In other words, sustainable supply chain practices on their own contribute to enterprises' sustainability, but the contributions are significantly better if agile capabilities facilitate sustainable supply chain practices.

Table 7. Significant of relationships identified for the hypotheses

\begin{tabular}{|c|c|c|c|c|c|}
\hline \multicolumn{3}{|c|}{ Correlation } & Hypothesis & Standard coefficient & t-values \\
\hline Agile practices & $\rightarrow$ & Sustainability performance & H1 & 0.407 & 2.944 \\
\hline Agile practices & $\rightarrow$ & $\begin{array}{l}\text { Operational performance } \\
\text { objectives }\end{array}$ & $\mathrm{H} 2$ & 0.537 & 5.706 \\
\hline $\begin{array}{l}\text { Sustainable supply chain } \\
\text { practices }\end{array}$ & $\rightarrow$ & Sustainability performance & $\mathrm{H} 3$ & 0.750 & 3.688 \\
\hline $\begin{array}{l}\text { Sustainable supply chain } \\
\text { practices }\end{array}$ & $\rightarrow$ & $\begin{array}{l}\text { Operational performance } \\
\text { objectives }\end{array}$ & H4 & 0.205 & 2.046 \\
\hline $\begin{array}{l}\text { Sustainable supply chain } \\
\text { practices }\end{array}$ & $\rightarrow$ & Agile practices & $\mathrm{H} 7$ & 0.327 & 1.704 \\
\hline
\end{tabular}

$*, * *, * * *$ indicates the significance of the $\mathrm{p}$ value at $<0.05 ;<0.01,<0.001$

$\mathrm{n}=311$, Estimation Method $=$ Maximum Likelihood.

Model fit indexes: $\mathrm{CMIN} / \mathrm{DF}=1.597 ; \mathrm{CFI}=0.947 ; \mathrm{TLI}=0.945 ; \mathrm{IFI}=0.947 ;$ and $\mathrm{RMSEA}=0.044$

\section{Table 8: Hypotheses testing results}

\begin{tabular}{|l|c|c|l|l|}
\hline Correlations & $\begin{array}{l}\text { Direct } \\
\text { effect }\end{array}$ & Indirect effect & Total effect & Results \\
\hline H1: Agile practices $\rightarrow$ sustainability performance & 0.407 & 0.000 & 0.407 & supported \\
\hline H2: Agile practices $\rightarrow$ operational performance objectives & 0.537 & 0.000 & 0.537 & supported \\
\hline $\begin{array}{l}\text { H3: Sustainable supply chain practices } \rightarrow \text { sustainability } \\
\text { performance }\end{array}$ & 0.750 & 0.000 & 0.750 & supported \\
\hline
\end{tabular}




\begin{tabular}{|l|c|c|l|l|}
\hline Correlations & $\begin{array}{l}\text { Direct } \\
\text { effect }\end{array}$ & Indirect effect & Total effect & Results \\
\hline $\begin{array}{l}\text { H4: Sustainable supply chain practices } \rightarrow \text { operational performance } \\
\text { objectives }\end{array}$ & 0.205 & 0.000 & 0.205 & supported \\
\hline $\begin{array}{l}\text { H5: Sustainable supply chain practices } \rightarrow \text { agile practices } \\
\rightarrow \text { sustainability performance }\end{array}$ & 0.750 & 0.135 & 0.885 & supported \\
\hline $\begin{array}{l}\text { H6: Sustainable supply chain practices } \rightarrow \text { agile practices } \\
\rightarrow \text { operational performance objectives }\end{array}$ & 0.205 & 0.172 & 0.377 & supported \\
\hline H7: Sustainable supply chain practices $\rightarrow$ agile practices & 0.327 & 0.000 & 0.327 & supported \\
\hline
\end{tabular}

\section{4: Discussion of results and implications}

\subsection{The effect of sustainable supply chain practices on agile practices}

The outcome of this study shows that there is a significant correlation between sustainable supply chain practices and agile practices in the UK manufacturing industry. Thus, it can be argued that the higher the implementation of sustainable supply chain practices, the greater the likelihood that agile capabilities will develop. The ability of organisations to design and create new sustainable products may lead to the development of agile practices. This seems to indicate that the constraints and challenges posed by social and natural environment are drivers of new capability development for firms. Further inspection of the hypothesised tests indicates that sustainable practices explained more than 16 per cent of the variance in agile practices. This suggests that agility capabilities are likely to emerge during a period of greater social and environmental changes. In this regard, we assume that agile capabilities evolve as a result of organisations' responses to consumer demand for sustainable products.

\subsubsection{The effect of agile practices on sustainability performance and operational performance}

The results also show that agile practices have strong positive and significant effect on sustainability performance and operational performance. These findings are consistent with prior studies, which noted that the higher the level of agility approaches, indeed the greater the increase in overall organisational performance (Tse et al., 2016; Eckstein et al., 2015; Yusuf et al., 2014; de Groote and Marx, 2013; Blome et al., 2013). Suffices to state that whilst the link between agility and operational performance is not new, what is new here is the connection between agile practices and sustainability performance. The agile practices seem to account for more than 69 and 43 per cent of the variance in sustainability 
performance and operational performance respectively. As changing climate will make resources becoming scarce, using market-sensing capability and advanced technology can facilitate the reduction of social and environmental impacts. Further, they can help identify ways to eliminate waste, minimise materials input, water and energy consumption in manufacturing. Additionally, joint effort with suppliers for sustainable procurement and process development will reduce toxic chemicals during production. Since these capabilities are socially created with suppliers, customers and other stakeholders, they can be a source of operational performance while also leading to improved sustainable supply chain performance.

\subsubsection{The effect of sustainable practices on operational and sustainability performance}

We found that sustainable supply chain practices have a positive and significant effect on both sustainability and operational performance. These results point out that sustainable supply chain practices are essential for differentiating products in the market place, and for additional and innovative value-creation. Through sustainable practices, the UK companies can realise significant savings, resulting in a cost advantage relative to their competitors. In fact, sustainable supply chain practices can save not only the cost of operations, but it can also boost productivity and increased energy efficiency. Less waste means better use of material inputs, resulting in lower cost for raw materials and waste disposal. For the same reason, sustainable practices may reduce cycle time by removing non-value adding activities. More so, a shift towards a circular flow of product, sustainable product design and socially responsible behaviours could provide UK manufacturing firms with the potential to cut emissions well below required levels, lessening the organisation's compliance costs, which, ultimately result in enhanced cash flow and profitability or new revenue streams for the supply chain. Whilst other studies appeared to suggest that SSCM practices have damaging effects on operational and financial performance (Esfahbodi et al., 2017; Zhu et al., 2007; Zhu et al., 2013), our findings provide strong empirical evidence that the implementation of SSCM practices will lead to better sustainability performance as well as better organisational performance in terms of cost, quality, speed, flexibility and innovation. 


\subsubsection{The mediating role of agile practices}

This study further confirms the mediating role of agile practices in the relationship between sustainable supply chain practices and organisational performance. This research contradicts Hong et al. (2018) findings, which predicted that supply chain capabilities has no effect on both economic and social performance. As already mentioned, the successful implementation of sustainability practices depends greatly on knowledge of customers and other stakeholders. The market sensing capability of an agile organisation can help in understanding the expectations of customers whilst the lack of sensing capability could render sustainability initiatives unsuccessful (Wu et al., 2016a). As insights from customers can help shape platforms that create maximum return for organisations, agile organisations with market sensing capabilities can quickly leverage on the understanding of customers and information technology to improve sustainability. Several organisations have improved sustainability performance through collective effort and collaboration with network members on sustainable supply chain initiatives.

\subsection{Theoretical implications}

The growing competition for resources and a changing climate have forced manufacturers to act in order to safeguard their future competitiveness. The dynamic capability theory (Beske et al., 2014; Aslam et al., 2018; Blome et al., 2014; Dubey et al., 2018) can offer important support to the progress of competitive advantage. This is envisaged based on the fact that sustainable competitive objectives depend largely on the organisation's ability to integrate, build and reconfigure internal and external resource competencies to address rapidly changing environment. In this regard, this study advances the knowledge of sustainability and operational strategy by exploring the performance effects of agility and sustainable supply chain practices. Our finding confirms that sustainable supply chain practices are drivers of agile capabilities. Further, the result indicates that agile practices, in turn, have impacts on both sustainability performance and operational performance. From the analysis, it is evident that the 
implementation of the respective dimensions of sustainable practices including sustainable products design, waste reduction initiatives and socially responsible behaviours are supporting organisations to reach expected sustainable competitive objectives. This result has important implications both for operations strategy and sustainability field. Thus, this study contributes to the wider literature in our discipline by providing empirical evidence on the influence of a set of agility and sustainable practices on organisational performance. More importantly, we break new grounds by examining the sustainability performance enhancing and amplification role agility plays as a mediator in the relationship between sustainable practices and the duo of operational performance and sustainability performance.

\subsection{Managerial implications}

This study provides several insights into how organisations can adapt to social and environmental changes in the supply chain. A shift to more sustainable manufacturing will be critical, requiring manufacturers to use less material, water, energy and other inputs; make better use of alternative materials. Sustainable products design will be important in helping the economic sustainability and competitiveness of organisations and will make valuable contributions to social and environmental sustainability. Managers should implement sustainable and agile strategies concurrently to optimise the development of agile capabilities. Our result also emphasises the importance of suppliers' involvement in sustainability initiatives. Therefore, we argue the need for close collaborative relationships amongst suppliers, customers, and other stakeholders in order to resolve social and environmental problems. In conclusion, our research examined the intervening effect of agile practices in the links between sustainable practices and organisational performance. As resources are increasingly becoming scarce, using advanced technology, as Yusuf et al (2014) contended, will reduce energy, water and raw materials usage. Sustainable technology will allow companies to reduce material or energy use to levels considered sustainable in the longer term. It will provide clean energy to everyday products, which can improve sustainability performance. Finally, managers who want to maximise the outcomes of their 
sustainability campaigns should consider concurrent implementation of both sustainable practices and agile practices.

\section{Conclusions and further research}

The results of this study advance the knowledge of sustainability practices and provide confirmation regarding the role of agile practices as enablers of sustainability performance. We adopt the dynamic capability view to examine the interactive effects between agile practices, sustainable practices, operational performance and sustainability performance of the supply chain. We provide empirical evidence of sustainability approaches as drivers for the development of agile capabilities. More so, there is a clear indication of a strong positive and significant effect of agile practices on sustainability performance. The research findings also demonstrate that sustainability practices are direct sources of sustainable competitiveness, but their performance impacts are improved when facilitated through agile practices. This suggests that agile capabilities are necessary conditions for maximising the impacts of implementation of sustainability practices on enterprise performance. We offer managerial insights into the outcome of agility and the degree to which the performance of sustainable product design, investment recovery, health and safety, and a broader socially responsible behaviour collectively can be achieved.

Although sustainable supply chain practices are a multidimensional construct, we only focused on five key first-order constructs of social sustainability practices, investment recovery, sustainable design, sustainable procurement and environmental management practices as a source for valuable agile capabilities. Further research can explore what other dimensions of sustainable supply chain practices lead to the development of agile supply chain capabilities. Further research could also look at which groups of agile companies have a greater (or the greatest) impacts on specific performance objectives.

Another limitation is that the study was focused primarily on data drawn from higher carbon and energy intensive supply chains in the UK. Therefore, the results may not be an accurate reflection of what obtains in the less carbon intensive segment of the economy. There is an ongoing attempt to conduct 
longitudinal case studies at some of the participant organisations to corroborate and strengthen the findings of this study. This will offer an opportunity for further studies. Finally, it is likely that the results of this study are limited to the UK context where practices like public awareness and strict regulations of social and environmental problems are perhaps more widespread than many other countries. Further research thus can replicate and extend the study in other countries, especially the developing countries that are often beset with relatively weaker institutions.

\section{References}

Adham, K., Siwar, C. and Bhuiyan, M., 2015. An overview of Malaysian government initiatives on sustainable consumption and production practices. OIDA International Journal of Sustainable Development, 8(06), pp.23-32.

Ageron, B., Gunasekaran, A. and Spalanzani, A. 2012. "Sustainable supply management: an empirical study", International Journal of Production Economics, Vol. 140 No. 1, pp. 168-182.

Armstrong, J.S. and Overton, T.S. 1977. "Estimating nonresponse bias in mail surveys”, Journal of Marketing Research, Vol. 14 No. 3, pp. 396-402.

Aslam, H., Blome, C., Roscoe, S. and Azhar, T.M., 2018. Dynamic supply chain capabilities: How market sensing, supply chain agility and adaptability affect supply chain ambidexterity. International Journal of Operations \& Production Management, 38(12), pp.2266-2285.

Augier, M. and Teece, D.J. 2009. "Dynamic capabilities and the role of managers in business strategy and economic performance", Organization Science, 20(2), pp. 410-421.

Azevedo, S. G., Carvalho, H., Duarte, S., \& Cruz-Machado, V. 2012. Influence of green and lean upstream supply chain management practices on business sustainability. IEEE Transactions on Engineering Management, 59(4), pp. 753-765.

Barney, J. 1991. Firm resources and sustained competitive advantage. Journal of management, 17(1), 99-120.

Bartlett, M. S. 1954. A note on the multiplying factors for various $\chi 2$ approximations. Journal of the Royal Statistical Society. Series B (Methodological), pp. 296-298.

Bell, E., Bryman, A., \& Harley, B. 2018. Business research methods. Oxford university press, UK.

Beske-Janssen, P., Johnson, M.P. and Schaltegger, S., 2015. 20 years of performance measurement in sustainable supply chain management-what has been achieved?. Supply chain management: An international Journal, 20(6), pp.664-680. 
Beske, P., Land, A. and Seuring, S. 2014. "Sustainable supply chain management practices and dynamic capabilities in the food industry: a critical analysis of the literature", International Journal of Production Economics, 152 (2014), pp. 131-143.

Blome, C., Schoenherr, T. and Rexhausen, D., 2013. Antecedents and enablers of supply chain agility and its effect on performance: a dynamic capabilities perspective. International Journal of Production Research, 51(4), pp.1295-1318.

Blome, C., T. Schoenherr and D. Eckstein 2014. 'The impact of knowledge transfer and complexity on supply chain flexibility: A knowledge-based view', International Journal of Production Economics, 147(2014), pp. 307-316

Bottani, E., 2010. Profile and enablers of agile companies: An empirical investigation. International Journal of Production Economics, 125(2), pp.251-261.

Byrne, B.M., 2016. Structural Equation Modeling with AMOS: Basic Concepts, Applications, and Programming. Routledge.

Cabral, I., Grilo, A. and Cruz-Machado, V., 2012. A decision-making model for lean, agile, resilient and green supply chain management. International Journal of Production Research, 50(17), pp.4830-4845.

Carter, C.R. and Rogers, D.S., 2008. A framework of sustainable supply chain management: moving toward new theory. International journal of physical distribution \& logistics management, 38(5), pp.360-387.

Carvalho, A.M., Sampaio, P., Rebentisch, E., Carvalho, J.Á. and Saraiva, P., 2017. Operational excellence, organisational culture and agility: the missing link?. Total Quality Management \& Business Excellence, pp.1-20.

Chen, L., Zhao, X., Tang, O., Price, L., Zhang, S. and Zhu, W., 2017. Supply chain collaboration for sustainability: A literature review and future research agenda. International Journal of Production Economics, 194, pp.73-87.

Chin, T. A., H. H. Tat and Z. Sulaiman 2015. 'Green supply chain management, environmental collaboration and sustainability performance', Procedia CIRP, 26(2015), pp. 695-699.

Choi, D. and Hwang, T., 2015. The impact of green supply chain management practices on firm performance: the role of collaborative capability. Operations Management Research, 8(3-4), pp.69-83.

Christmann, P. 2000. 'Effects of "best practices" of environmental management on cost advantage: The role of complementary assets', Academy of Management journal, 43(4), 663-680.

Christopher, M. 2016. Logistics \& supply chain management: Pearson UK.

Ciccullo, F., Pero, M., Caridi, M., Gosling, J. and Purvis, L., 2018. Integrating the environmental and social sustainability pillars into the lean and agile supply chain management paradigms: A literature review and future research directions. Journal of Cleaner Production, 172(2018), pp.2336-2350. 
Conforto, E.C., Salum, F., Amaral, D.C., Da Silva, S.L. and De Almeida, L.F.M., 2014. Can agile project management be adopted by industries other than software development?. Project Management Journal, 45(3), pp.21-34.

Creswell, J. W. 2014. A concise introduction to mixed methods research. Sage Publications.

Crittenden, V. L., W. F. Crittenden, L. K. Ferrell, O. Ferrell and C. C. Pinney 2011. 'Market-oriented sustainability: a conceptual framework and propositions', Journal of the Academy of Marketing Science, 39(1), pp. 71-85.

Dangelico, R. M. and D. Pujari 2010. 'Mainstreaming green product innovation: Why and how companies integrate environmental sustainability', Journal of Business Ethics, 95(3), pp. 471-486.

de Groote, S.E. and Marx, T.G., 2013. The impact of IT on supply chain agility and firm performance: An empirical investigation. International Journal of Information Management, 33(6), pp.909-916.

DeVellis, R. F. 2016. Scale development: Theory and applications (Vol. 26). Sage publications.

Dillman, D. A., Smyth, J. D. and Christian, L. M. 2014. Internet, phone, mail, and mixed-mode surveys: the tailored design method. John Wiley \& Sons.

Dubey, R., Altay, N., Gunasekaran, A., Blome, C., Papadopoulos, T. and Childe, S.J., 2018. Supply chain agility, adaptability and alignment: empirical evidence from the Indian auto components industry. International Journal of Operations \& Production Management, 38(1), pp.129-148.

Dubey, R., Gunasekaran, A. and Ali, S. S. 2015. Exploring the relationship between leadership, operational practices, institutional pressures and environmental performance: A framework for green supply chain. International Journal of Production Economics, 160(2015), 120-132.

Dües, C. M., Tan, K. H., and Lim, M. 2013. Green as the new Lean: how to use Lean practices as a catalyst to greening your supply chain. Journal of cleaner production, 40(1), 93-100.

Dyer, J. H., \& Singh, H. 1998. The relational view: Cooperative strategy and sources of interorganisational competitive advantage. Academy of management review, 23(4), 660-679.

Dyer, J. H., Singh, H., \& Hesterly, W. S. 2018. The relational view revisited: A dynamic perspective on value creation and value capture. Strategic Management Journal, 39(12), 3140-3162.

Easterby-Smith, M., Thorpe, R., Jackson, P. R., \& Jaspersen, L. J. 2018. Management and business research. Sage, UK.

Eckstein, D., Goellner, M., Blome, C. and Henke, M., 2015. The performance impact of supply chain agility and supply chain adaptability: the moderating effect of product complexity. International Journal of Production Research, 53(10), pp.30283046. 
Esfahbodi, A., Zhang, Y., \& Watson, G. 2016. Sustainable supply chain management in emerging economies: Trade-offs between environmental and cost performance. International Journal of Production Economics, 181(1), 350-366.

Esfahbodi, A., Zhang, Y., Watson, G. and Zhang, T., 2017. Governance pressures and performance outcomes of sustainable supply chain management-An empirical analysis of UK manufacturing industry. Journal of cleaner production, 155, pp.6678.

Fornell, C. and Larcker, D.F. 1981. "Evaluating structural equation models with unobservable variables and measurement error”, Journal of Marketing Research, 18 (1), pp. 39-50.

Frankfort-Nachmias, C., and Nachmias, D. 2007. Study guide for research methods in the social sciences. Macmillan.

Fullerton, R. R., Kennedy, F. A., \& Widener, S. K. 2014. Lean manufacturing and firm performance: The incremental contribution of lean management accounting practices. Journal of Operations Management, 32(7-8), 414-428.

Geissdoerfer, M., Morioka, S.N., de Carvalho, M.M. and Evans, S., 2018. Business models and supply chains for the circular economy. Journal of Cleaner Production, 190, pp.712-721.

Gligor, D.M., Holcomb, M.C. and Feizabadi, J., 2016. An exploration of the strategic antecedents of firm supply chain agility: The role of a firm's orientations. International Journal of Production Economics, 179, pp.24-34.

Goldman, S.L., 1995. Agile competitors and virtual organizations. Strategies for enriching the customer. New York, NY: Van Nostrand Reinhold

Golicic, S. L., \& Smith, C. D. 2013. A meta-analysis of environmentally sustainable supply chain management practices and firm performance. Journal of Supply Chain Management, 49(2), pp. 78-95.

Gordon, J. and S. Sohal, A., 2001. Assessing manufacturing plant competitiveness-An empirical field study. International Journal of Operations \& Production Management, 21(1/2), pp.233-253.

Green, K.W., Toms, L.C., Clark, J., 2015. Impact of market orientation on environmental sustainability strategy. Manag. Res. Rev. 38 (2), 217-238.

Grimm, J.H., Hofstetter, J.S. and Sarkis, J., 2014. Critical factors for sub-supplier management: A sustainable food supply chains perspective. International Journal of Production Economics, 152, pp.159-173.

Guisado-González, M., Guisado-Tato, M. and Ferro-Soto, C. 2016. 'The interaction of technological innovation and increases in productive capacity: Multiplication of loaves and fishes?', South African Journal of Business Management, 47(2), pp. 4351.

Gunasekaran, A., Yusuf, Y.Y., Adeleye, E.O., Papadopoulos, T., Kovvuri, D. and Geyi, D. G., 2018. Agile manufacturing: an evolutionary review of practices. International Journal of Production Research, pp.1-21. 
Hahn, T., Figge, F., Pinkse, J., \& Preuss, L. 2010. Trade-offs in corporate sustainability: You can't have your cake and eat it. Business Strategy and the Environment, 19(4), pp. 217-229.

Hair, J. F., Black, W. C., Babin, B. J., Anderson, R. E., and Tatham, R. L. 2010. Multivariate data analysis, 6 ed. PrenticeHall, New Jersey.

Hair, J.F., Black, W.C., Babin, B.J. and Anderson, R.E. 2014. Multivariate Data Analysis, Pearson Education Limited, Essex.

Hannibal, C., \& Kauppi, K. 2018. Third party social sustainability assessment: Is it a multi-tier supply chain solution? International Journal of Production Economics.

Hart, S. L., \& Dowell, G. 2011. Invited editorial: a natural-resource-based view of the firm: fifteen years after. Journal of management, 37(5), 1464-1479.

Hart, S.L., 1995. A natural-resource-based view of the firm. Academy of Management Review, 20 (4), pp. $986-1014$.

Hofmann, H., Schleper, M.C. and Blome, C., 2018. Conflict minerals and supply chain due diligence: an exploratory study of multi-tier supply chains. Journal of Business Ethics, 147(1), pp.115-141.

Hong, J., Zhang, Y. and Ding, M., 2018. Sustainable supply chain management practices, supply chain dynamic capabilities, and enterprise performance. Journal of Cleaner Production, 172, pp.3508-3519.

Hu, L. t. and Bentler, P.M. 1999. "Cutoff criteria for fit indexes in covariance structure analysis: conventional criteria versus new alternatives”, Structural Equation Modelling: A Multidisciplinary Journal, 6 (1), pp. 1-55.

Huq, F. A., Chowdhury, I. N., \& Klassen, R. D. 2016. Social management capabilities of multinational buying firms and their emerging market suppliers: An exploratory study of the clothing industry. Journal of Operations Management, 46, 19-37.

Jabbour, C.J.C., de Sousa Jabbour, A.B.L. and Sarkis, J., 2018. Unlocking effective multi-tier supply chain management for sustainability through quantitative modelling: Lessons learned and discoveries to be made. International Journal of Production Economics, $\mathrm{xxx}(\mathrm{xxxx}) \mathrm{xxx}-\mathrm{xxx}$

Jadhav, A., Orr, S., \& Malik, M. 2018. The role of supply chain orientation in achieving supply chain sustainability. International Journal of Production Economics.

Jennings, M.M. (2013), "Social responsibility and ethical considerations in the management of the supply chain", in Harland, C., Nassimbeni, G. and Schneller, E. (Eds), The SAGE Handbook of Strategic Supply Management, SAGE, Los Angeles, CA, pp. 331-352.

Kaiser, H.F., 1974. An index of factorial simplicity. Psychometrika 39 (1), 31-36.

Kaplan, R.S. and Norton, D.P., 1992. The balanced scorecard: measures that drive performance. 
Ketchen Jr, D.J. and Hult, G.T.M., 2007. Bridging organization theory and supply chain management: The case of best value supply chains. Journal of operations management, 25(2), pp.573-580.

Klassen, R.D. and Vereecke, A., 2012. Social issues in supply chains: Capabilities link responsibility, risk (opportunity), and performance. International Journal of production economics, 140(1), pp.103-115.

Kleindorfer, P. R., Singhal, K., \& Van Wassenhove, L. N. 2005. Sustainable Operations Management. Production and Operations Management, 14 (4), 482-492.

Koufteros, X. A. 1999. Testing a model of pull production: a paradigm for manufacturing research using structural equation modelling. Journal of operations Management, 17(4), 467-488.

Krause, D. R., Vachon, S., \& Klassen, R. D. 2009. Special topic forum on sustainable supply chain management: Introductions and reflections on the role of purchasing management. Journal of Supply Chain Management, 45(4), 18-25.

Lambert, D.M., Enz, M.G., 2017. Issues in supply chain management: progress and potential. Ind. Market. Manag. 62, 1-16.

Large, R. O. and Thomsen, C. G. 2011. Drivers of green supply management performance: Evidence from Germany. Journal of Purchasing and Supply Management, 17(3), 176-184.8

Lavie, D., 2006. The competitive advantage of interconnected firms: An extension of the resource-based view. Academy of management review, 31(3), pp.638-658.

Lee, H.L. 2004. “The triple-A supply chain”, Harvard Business Review, 82 (10), pp. 102-113.

Lin, C. T., Chiu, H., and Tseng, Y. H. 2006. Agility evaluation using fuzzy logic. International Journal of Production Economics, 101(2), 353-368.

Luthra, S., Mangla, S.K., Xu, L. and Diabat, A., 2016. Using AHP to evaluate barriers in adopting sustainable consumption and production initiatives in a supply chain. International Journal of Production Economics, 181, pp.342-349.

MacKinnon, D. P., Lockwood, C. M., Hoffman, J. M., West, S. G., \& Sheets, V. 2002. A comparison of methods to test mediation and other intervening variable effects. Psychological methods, 7(1), 83.

Mani, V., Gunasekaran, A., and Delgado, C. 2018. Enhancing supply chain performance through supplier social sustainability: An emerging economy perspective. International Journal of Production Economics, 195, 259-272.

Marshall, A.P., Fisher, M.J., Brammer, J., Eustace, P., Grech, C., Jones, B., Kelly, M., 2007. Assessing psychometric properties of scales: a case study. J. Adv. Nurs. 59 (4), 398-406.

Marshall, D., McCarthy, L., Heavey, C., and McGrath, P. 2015. Environmental and social supply chain management sustainability practices: construct development and measurement. Production Planning \& Control, 26(8), 673-690. 
Martinez-Sanchez, A. and Lahoz-Leo, F., 2018. Supply chain agility: a mediator for absorptive capacity. Baltic Journal of Management, 13(2), pp.264-278.

Mathiyakalan, S., Ashrafi, N., Zhang, W., Waage, F., Kuilboer, J.P. and Heimann, D., 2005, May. Defining business agility: an exploratory study. In Proceedings of the 16th Information Resources Management Conference, San Diego, CA (pp. 15-18).

McKinsey 2013. “The business of sustainability”, Report McKinsey, summer 2012, New York, NY.

McWilliams, A., and Siegel, D. 2001. Corporate social responsibility: A theory of the firm perspective. Academy of management review, 26(1), 117-127.

Morais, D.O. and Silvestre, B.S., 2018. Advancing social sustainability in supply chain management: Lessons from multiple case studies in an emerging economy. Journal of cleaner production, 199, pp.222-235.

Morali, O. and Searcy, C. 2013. A review of sustainable supply chain management practices in Canada. Journal of Business Ethics, 117(3), 635-658

Nasir, M., Nawaz, M.H., Latif, U., Yaqub, M., Hayat, A. and Rahim, A., 2017. An overview on enzyme-mimicking nanomaterials for use in electrochemical and optical assays. Microchimica Acta, 184(2), pp.323-342.

Naylor, J.B., Naim, M.M. and Berry, D., 1999. Leagility: integrating the lean and agile manufacturing paradigms in the total supply chain. International Journal of production economics, 62(1-2), pp.107-118.

Neely, A., Gregory, M. and Platts, K., 2005. Performance measurement system design: A literature review and research agenda. International journal of operations \& production management, 25(12), pp.1228-1263.

Orlitzky, M., Siegel, D.S. and Waldman, D.A. 2011. "Strategic corporate social responsibility and environmental sustainability”, Business \& Society, Vol. 50 (1): 6-27.

Orsato, R. J. 2006. Competitive environmental strategies: when does it pay to be green? California management review, 48(2), 127-143.

Orzes, G., Jia, F., Sartor, M. and Nassimbeni, G., 2017. Performance implications of SA8000 certification. International Journal of Operations \& Production Management, 37(11), pp.1625-1653.

Pagell, M., \& Shevchenko, A. (2014). Why research in sustainable supply chain management should have no future. Journal of Supply Chain Management, 50(1), 44-55.

Pagell, M., Yang, C. L., Krumwiede, D. W. and Sheu, C. 2004. Does the competitive environment influence the efficacy of investments in environmental management? Journal of Supply Chain Management, 40(2), 30-39.

Pallant, J. 2013. SPSS survival manual. McGraw-Hill Education (UK). 
Paulraj, A., I. J. Chen and C. Blome 2017. 'Motives and performance outcomes of sustainable supply chain management practices: A multi-theoretical perspective', Journal of Business Ethics, 145, pp. 239-258.

Pierre, C., Francesco, P., \& Theo, N. 2019. Towards low carbon global supply chains: A multi-trade analysis of CO2 emission reductions in container shipping. International Journal of Production Economics, 208, 17-28.

Podsakoff, P.M., MacKenzie, S.B., Lee, J.-Y. and Podsakoff, N.P. 2003. "Common method biases in behavioural research: a critical review of the literature and recommended remedies”, Journal of Applied Psychology, Vol. 88 No. 5, pp. 879-903.

Porter, M.E. and Kramer, M.R. 2006. Strategy \& society: the link between competitive advantage and corporate social responsibility, Harvard Business Review, 84(12), pp. 78-92

Porter, M.E. and van der Linde, C. 1995. "Green and competitive: ending the stalemate”, Harvard Business Review, 73 (5), pp. 120-134.

Porter, M.E., 2004. Competitive advantage: creating and sustaining superior performance: with a new introduction. Free Press.

Prajogo, D., A. KY Tang and K. Lai 2014. The diffusion of environmental management system and its effect on environmental management practices, International Journal of Operations \& Production Management, 34, pp. 565-585.

Rao, P., \& Holt, D. 2005. Do green supply chains lead to competitiveness and economic performance? International Journal of Operations \& Production Management, 25(9), pp. 898916.

Ren, J., Yusuf, Y. Y. and Burns, N. D. 2003. The effects of agile attributes on competitive priorities: a neural network approach. Integrated Manufacturing Systems, 14(6), 489-497.

Roy, V., Schoenherr, T., and Charan, P. 2018. The thematic landscape of literature in sustainable supply chain management (SSCM) a review of the principal facets in SSCM development. International Journal of Operations \& Production Management, 38(4), 1091-1124.

Rungtusanatham, M., Salvador, F., Forza, C. and Choi, T. Y. 2003. Supply-chain linkages and operational performance: A resource-based-view perspective. International Journal of Operations \& Production Management, 23(9), 1084-1099.

Sancha, C., Gimenez, C. and Sierra, V., 2016. Achieving a socially responsible supply chain through assessment and collaboration. Journal of Cleaner Production, 112, pp.1934-1947.

Sarkis, J., Gonzalez-Torre, P., \& Adenso-Diaz, B. 2010. Stakeholder pressure and the adoption of environmental practices: The mediating effect of training. Journal of Operations Management, 28(2), 163-176.

Sarkis, J., Zhu, Q., \& Lai, K. 2011. An organizational theoretic review of green supply chain management literature. International Journal of Production Economics, 130(1), 1-15. 
Serrador, P., \& Pinto, J. K. 2015. Does agile work? -A quantitative analysis of agile project success. International Journal of Project Management, 33(5), 1040-1051.

Sobel, M. E. 1982. “Asymptotic Confidence Intervals for Indirect Effects in Structural Equation Models.” Sociological Methodology 13 (1982): 290-312.

Song, M., Zheng, W., \& Wang, Z. 2016. Environmental efficiency and energy consumption of highway transportation systems in China. International Journal of Production Economics, 181, 441-449.

Stindt, D., Sahamie, R., Nuss, C., Tuma, A., 2016. How transdisciplinary can help to improve operations research on sustainable supply chains—a transdisciplinary modeling framework. J. Bus. Logist. 37 (2), 113-131.

Su, H.C., Dhanorkar, S. and Linderman, K., 2015. A competitive advantage from the implementation timing of ISO management standards. Journal of Operations Management, 37, pp.31-44.

Tabachnick, B. G., \& Fidell, L. S. 2014. Using multivariate statistics (new international ed. ed.). Harlow: Pearson.

Teece, D.J., Pisano, G. and Shuen, A., 1997. Dynamic capabilities and strategic management. Strategic management journal, 18(7), pp.509-533.

Tonelli, F., Evans, S. and Taticchi, P., 2013. Industrial sustainability: challenges, perspectives, actions. International Journal of Business Innovation and Research, 7(2), pp.143-163.

Treacy, R., Humphreys, P., McIvor, R. and Lo, C., 2019. ISO14001 certification and operating performance: A practice-based view. International Journal of Production Economics, 208, pp.319-328.

Tse, Y.K., Zhang, M., Akhtar, P. and MacBryde, J., 2016. Embracing supply chain agility: an investigation in the electronics industry. Supply Chain Management: An International Journal, 21(1), pp.140-156.

Vachon, S. and Klassen, R.D. 2006. "Extending green practices across the supply chain: the impact of upstream and downstream integration”, International Journal of Operations \& Production Management, Vol. 26 No. 7, pp. 795-821.

van Hoek, R., A. Harrison and M. Christopher 2001. 'Measuring agile capabilities in the supply chain', International Journal of Operations \& Production Management, 21, pp. 126-148.

Vinodh, S., Sundararaj, G. and Devadasan, S.R., 2010. Measuring organisational agility before and after implementation of TADS. The International Journal of Advanced Manufacturing Technology, 47(5-8), pp.809-818.

Walker, P.H., Seuring, P.S., Sarkis, P.J. and Klassen, P.R., 2014. Sustainable operations management: recent trends and future directions. International Journal of Operations \& Production Management, 34(5), pp. 1-11 
West, D. M. and Lansang, C., 2018, Report: Global manufacturing scorecard: How the US compares to 18 other nations, retrieved from Brookings.edu on 17/05/2019.

Wilhelm, M.M., Blome, C., Bhakoo, V. and Paulraj, A., 2016. Sustainability in multi-tier supply chains: Understanding the double agency role of the first-tier supplier. Journal of Operations Management, 41, pp.42-60.

Wilson, J. 2014. Essentials of business research: A guide to doing your research project. Sage.

Winn, M., Pinkse, J., \& Illge, L. 2012. Case studies on trade-offs in corporate sustainability. Corporate Social Responsibility and Environmental Management, 19(2), 63-68.

Wong, C. W. Y., Lai, K.-H., Shang, K.-C., Lu, C.-S., \& Leung, T. K. P. 2012. Green operations and the moderating role of environmental management capability of suppliers on manufacturing firm performance. International Journal of Production Economics, 140(1), 283-294

Wong, C.W., Wong, C.Y., Boon-itt, S., 2018. How does sustainable development of supply chains make firms lean, green and profitable? A resource orchestration perspective. Bus. Strat. Environ. 27 (3), 375-388.

Wu, J., Dunn, S. and Forman, H. (2012). “A study on green supply chain management practices among large global corporations”. Journal of Supply Chain and Operations Management, 10 (1),182-194.

Wu, K.J., Liao, C.J., Chen, C.C., Lin, Y. and Tsai, C.F., 2016. Exploring eco-innovation in dynamic organizational capability under incomplete information in the Taiwanese lighting industry. International Journal of Production Economics, 181, pp.419440.

Yusuf, Y. Y., Gunasekaran, A., Musa, A., Dauda, M., El-Berishy, N. M. and Cang, S. 2014. 'A relational study of supply chain agility, competitiveness and business performance in the oil and gas industry', International Journal of Production Economics, 147, pp. 531-543.

Yusuf, Y. Y., Gunasekaran, A., Musa, A., El-Berishy, N. M., Abubakar, T., and Ambursa, H. M. 2013. The UK oil and gas supply chains: An empirical analysis of adoption of sustainable measures and performance outcomes. International Journal of Production Economics, 146(2), 501-514.

Yusuf, Y., Gunasekaran, A., Papadopoulos, T., Auchterlounie, W., Hollomah, D. and Menhat, M., 2018. Performance measurement in the natural gas industry: A case study of Ghana's natural gas supply chain. Benchmarking: An International Journal, 25(8), pp.2913-2930.

Yusuf, Y.Y., Gunasekaran, A., Adeleye, E.O. and Sivayoganathan, K., 2004. Agile supply chain capabilities: Determinants of competitive objectives. European Journal of Operational Research, 159(2), pp.379-392. 
Zhu, Q. and Lai, K.H., 2019. Enhancing supply chain operations with extended corporate social responsibility practices by multinational enterprises: Social capital perspective from Chinese suppliers. International Journal of Production Economics, 213, pp.1-12.

Zhu, Q., \& Sarkis, J. 2004. Relationships between operational practices and performance among early adopters of green supply chain management practices in Chinese manufacturing enterprises. Journal of Operations Management, 22(3), pp. $265-289$.

Zhu, Q., and Sarkis, J. 2007. The moderating effects of institutional pressures on emergent green supply chain practices and performance. International journal of production research, 45(18-19), 4333-4355.

Zhu, Q., J. Sarkis and K. Lai 2013. 'Institutional-based antecedents and performance outcomes of internal and external green supply chain management practices', Journal of Purchasing and Supply Management, 19, pp. 106-117.

Zhu, Q., Sarkis, J. and Lai, K.H., 2007. Green supply chain management: pressures, practices and performance within the Chinese automobile industry. Journal of cleaner production, 15(11-12), pp.1041-1052.

Zhu, Q., Sarkis, J., and Lai, K. H. 2008. Green supply chain management implications for "closing the loop". Transportation Research Part E: Logistics and Transportation Review, 44(1), 1-18. 